\title{
17. MIDDLE AND LATE CENOZOIC PLANKTONIC FORAMINIFERAL BIOSTRATIGRAPHY OF THE SOUTHWEST PACIFIC-DSDP LEG 21
}

\author{
James P. Kennett, Graduate School of Oceanography, University of Rhode Island, Kingston, Rhode Island
}

\begin{abstract}
Planktonic foraminifera have been examined from eight DSDP sites in the southwest Pacific from the late Early Miocene to the Recent. The traverse of sites examined ranges from tropical to cool subtropical (temperate) regions. The stratigraphic ranges of the planktonic foraminifera of Middle to Late Cenozoic age in six of these sites are presented here. Large paleoenvironmental differences between the sites have made it necessary to use separate zonal schemes in cool subtropical (temperate), warm subtropical, and tropical areas. The planktonic foraminiferal zonations for the cool subtropical and warm subtropical regions are new. For the tropical sites the zonation scheme is that of Banner and Blow (1965) and Blow (1969). Species of Globorotalia represent the most useful forms for zonal subdivision and correlation with the region. In cool subtropical areas a valuable evolutionary bioseries is represented by gradation from Globorotalia miozea conoidea to $G$. conomiozea to $G$. puncticulata to $G$. inflata. In warm subtropical areas the evolution can also be observed from $G$. puncticulata to G. inflata. The ranges of numerous planktonic foraminifera differ markedly between the different regions because of the distinct environmental controls.

Sphaeroidinella dehiscens is of no value in the determination of the Miocene-Pliocene boundary throughout the area because it does not appear until the Middle Pliocene. In cool subtropical areas the first evolutionary appearance of Globorotalia puncticulata marks the boundary, while in warm subtropical areas this species appears later. In the warmer sites the first appearance of Globorotalia margaritae seems to be a reliable indication of the Miocene-Pliocene boundary.

The Pliocene-Pleistocene boundary is placed at the first appearance of Globorotalia truncatulinoides. In several sites the evolution of $G$. truncatulinoides from $G$. tosaensis near the boundary is not a simple continuum, but is marked by reversals in evolutionary trend that may be partly environmentally controlled.

Most of the important forms are illustrated by scanning electron micrographs.
\end{abstract}

\section{INTRODUCTION}

During Leg 21 of the Deep Sea Drilling Project, a total of eight sites cored yielded 1388 meters of core in the southwest Pacific (Figure 1). The coring of a series of sites ranging from present-day southern tropical latitudes $\left(14^{\circ}-15^{\circ} \mathrm{S}\right)$ to temperate latitudes $\left(37^{\circ} \mathrm{S}\right)$ has provided Late Cenozoic sequences containing assemblages that are in large part able to be correlated with those of the tropical and temperate regions. A high proportion of continuous coring and a high rate of core recovery at several sites have provided an excellent basis for detailed biostratigraphic and related studies. The rather shallow-water location of several sites has assured that the section contains rich assemblages of well-preserved foraminifera.

The stratigraphic distribution of Cenozoic to Late Cretaceous sediments recovered during Leg 21 is shown in Figure 2. Paleogene and Neogene sediments were recovered at all sites. The general planktonic foraminiferal biostratigraphy at each site is presented in Part I (this volume), Site Reports. The planktonic foraminiferal sequence of the Paleogene is disrupted by disconformities and sampling 


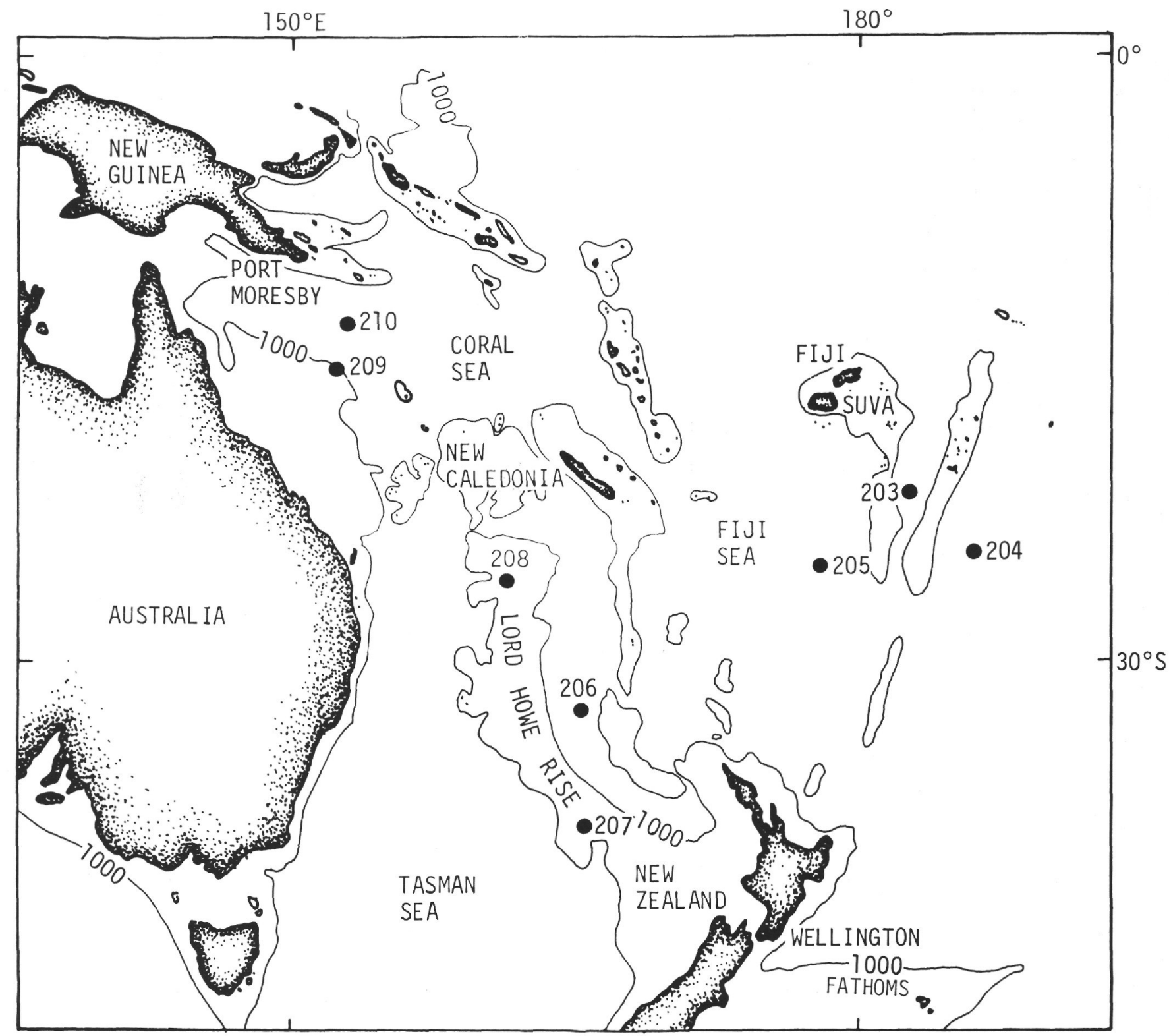

Figure 1. Location of DSDP Leg 21 sites.

gaps. In addition, planktonic foraminiferal preservation is commonly poor because of dissolution at various levels. In contrast, the Neogene sequences are typically continuous, contain rich calcareous assemblages, and have fewer sedimentary breaks.

This paper presents an account of the planktonic foraminiferal biostratigraphy from the late Early Miocene to the Recent. The stratigraphic ranges of species are charted for six of the eight sites (Figures 3 to 8 ), and the biostratigraphy is discussed. Regional trends of the planktonic foraminifera are discussed, and zonal schemes are presented for the three distinct water-mass regions cored.

Late Cenozoic planktonic foraminifera were recovered at all sites except Site 204 which is too deep for preservation of calcareous foraminifera. Locations and water depths of the other DSDP sites are shown in Table 1.
TABLE 1 Location and Water Depth of Sites, Leg 21

\begin{tabular}{cccc}
\hline Site & Latitude & Longitude & Depth $(\mathrm{m})$ \\
\hline 203 & $22^{\circ} 09.22^{\prime} \mathrm{S}$ & $177^{\circ} 32.77^{\prime} \mathrm{W}$ & 2720 \\
205 & $25^{\circ} 30.99^{\prime} \mathrm{S}$ & $177^{\circ} 53.95^{\prime} \mathrm{E}$ & 4320 \\
206 & $32^{\circ} 00.75^{\prime} \mathrm{S}$ & $165^{\circ} 27.15^{\prime} \mathrm{E}$ & 3196 \\
207 & $36^{\circ} 57.75^{\prime} \mathrm{S}$ & $165^{\circ} 26.06^{\prime} \mathrm{E}$ & 1389 \\
208 & $26^{\circ} 06.61^{\prime} \mathrm{S}$ & $161^{\circ} 13.27^{\prime} \mathrm{E}$ & 1545 \\
209 & $15^{\circ} 56.19^{\prime} \mathrm{S}$ & $152^{\circ} 11.27^{\prime} \mathrm{E}$ & 1428 \\
210 & $13^{\circ} 45.99^{\prime} \mathrm{S}$ & $152^{\circ} 53.78^{\prime} \mathrm{E}$ & 4643 \\
\hline
\end{tabular}

\section{GENERAL ASPECTS OF MIDDLE-LATE CENOZOIC OF SITES}

The planktonic foraminiferal biostratigraphy for each site is summarized in Part I (Site Summaries). General 


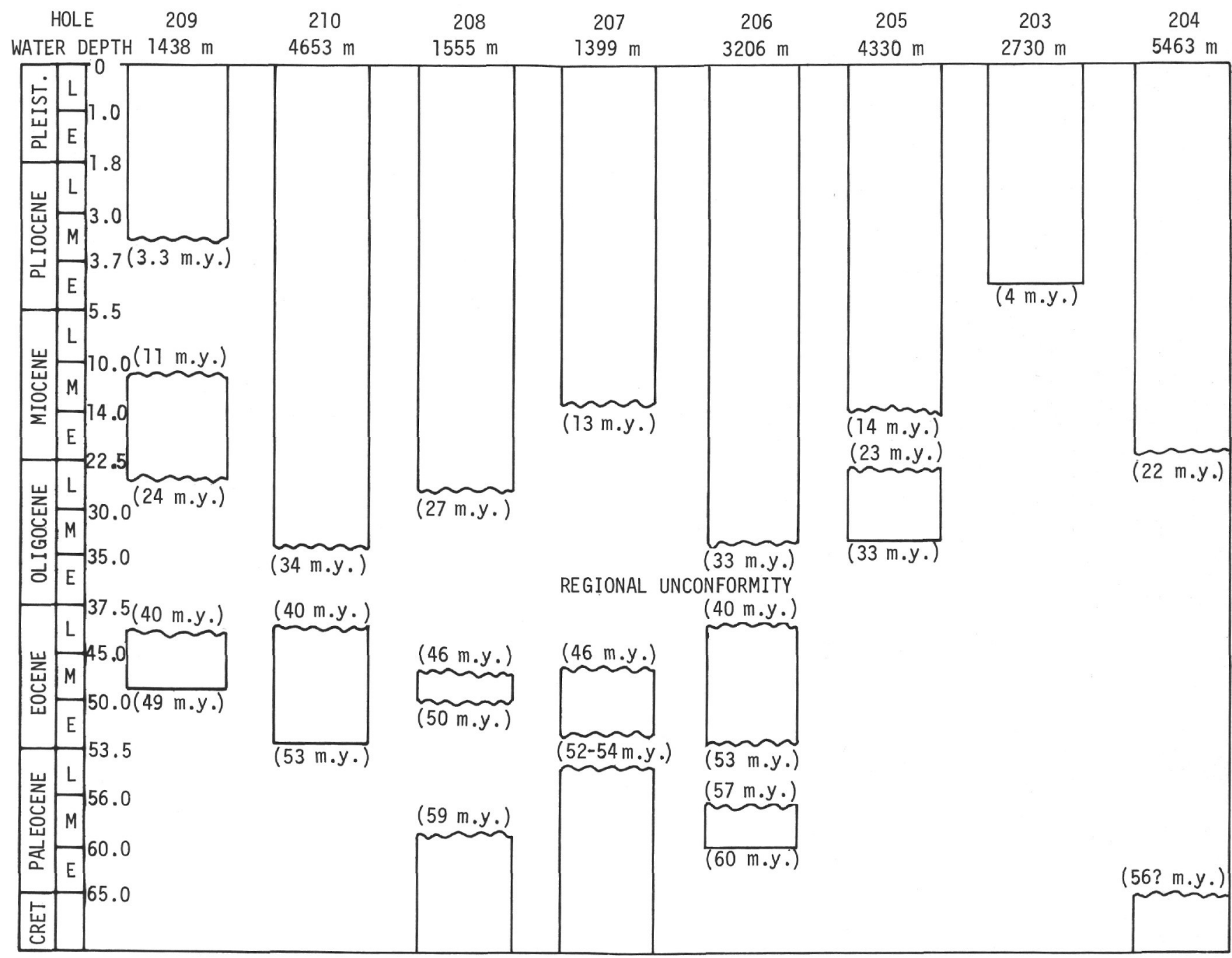

Figure 2. Stratigraphic distribution of sediments cored on Leg 21.

aspects of the Late Cenozoic are presented here. In almost all sites the Late Miocene to Recent was continuously cored and hence, is represented by remarkably complete sections. Sites 208, 206, and 207-207A are among the most valuable Late Cenozoic sections in the southern hemisphere, planktonic foraminifera being abundant and well preserved throughout. Site 210 also yielded abundant foraminifera, and though much deeper and affected by dissolution of tests, revealed important biostratigraphic information. Six sites were studied in detail. Disconformities were found in four of the sites, being minor in two cases (Sites 206 and 208), but major in the other two cases (Sites 207 and 209).

\section{Site 203}

Planktonic foraminifera are abundant and moderately well preserved in all five cores obtained from Site 203 which range in age from the Middle Pliocene to Recent. The assemblages are almost exclusively made up of tropical elements. The section if very thick (400 meters) owing to extensive nearby volcanism which provided abundant volcanic debris.
Site 204

This site at a depth of 5354 meters was of no value in this study because planktonic foraminifera are absent throughout due to dissolution.

\section{Site 205}

Pliocene to Pleistocene planktonic foraminiferal faunas are absent due to intense dissolution in the upper few meters of sediment in Site 205. The youngest planktonic foraminiferal faunas present (at 205-3-3, $115 \mathrm{~cm}$ ) are of Late Miocene age. Planktonic foraminifera occur in varying frequencies with moderate to good preservation in the Middle and Late Miocene down to Core 205-22. A summary of planktonic foraminiferal biostratigraphy for this site is given in Part I, this volume. No detailed studies of the planktonic foraminiferal biostratigraphy of this site were attempted because of the limited time to prepare this report.

\section{Site 206}

The late Early Miocene (Section 206-33-1) to Recent of this section is represented by about 300 meters of 


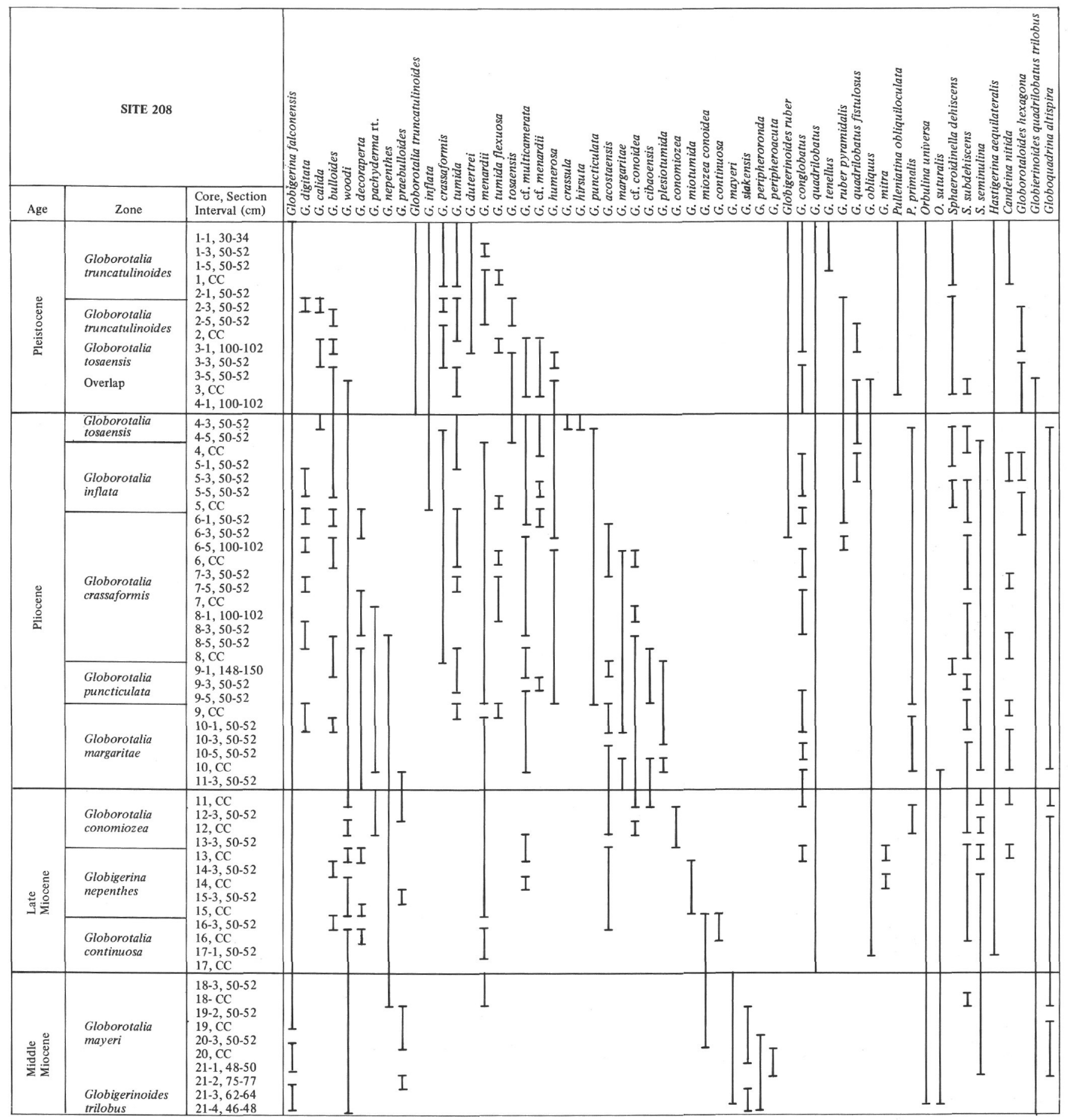

Figure 3. Distribution of planktonic foraminifera and zonation at Site 208.

foraminiferal-rich nanno oozes. Planktonic foraminifera are abundant and well preserved throughout. The section is one of the most continuous Middle to Late Cenozoic planktonic foraminiferal sequences in the southern hemisphere, one of the few available biostratigraphic sections in waters intermediate between tropical and temperate areas, and one of the finest Neogene deep-sea biostratigraphic sequences in the world. Faunas present throughout include both tropical forms (e.g., Globorotalia menardii and G. tumida) and temperate forms (e.g., G. inflata and Globigerina bulloides). One distinct disconformity occurs at the Miocene-Pliocene boundary, while a less distinct disconformity occurs between the Early and Middle Miocene. Particularly high sedimentation rates $(6 \mathrm{~cm} / 1000$ years $)$ characterize the Pleistocene which is thus potentially useful for detailed biostratigraphy. 


\section{Site 207-207A}

The upper 120 meters (Cores 207-1 to 207-5 and 207A-1 to 207A-8) at Site 207 is an apparently continuous Late Miocene to Recent section. This interval is represented by foraminiferal-rich nanno ooze containing abundant, well-preserved planktonic foraminifera. It represents the most continuous, cool subtropical (temperate) Late Cenozoic section described in the southern hemisphere. Temperate elements are dominant, while tropical elements are quite rare.

\section{Site 208}

At Site 208 an apparently continuous Middle Miocene to Recent section of foraminiferal-rich nanno ooze is 320 meters thick (208-1-1, $10 \mathrm{~cm}$ to $208-21-3,62 \mathrm{~cm})$ and provides the most complete Middle to Late Cenozoic planktonic foraminiferal sequence available in warm subtropical waters in the southern hemisphere. Planktonic foraminifera are abundant and well preserved throughout. Site 208 is of particular importance because the faunas are intermediate between tropical and temperate regions. A relatively minor disconformity separates Early and Middle Miocene faunas.

\section{Site 209}

At Site 209 an excellent biostratigraphic sequence of about 50 meters extends unbroken from the Middle Pliocene to the Recent (209-1-1 to 209-5-CC). Planktonic foraminifera are very well preserved throughout, with solution-susceptible forms remaining well preserved. The faunas are exclusively tropical. A disconformity separates Middle Pliocene from late Middle Miocene sediments. Low sample recovery in the Miocene prevented useful biostratigraphic studies on faunas of this age.

\section{Site 210}

At this site a very thick, apparently continuous, turbidite sequence $(450 \mathrm{~m})$ represents the Late Miocene to Recent. No detailed planktonic foraminiferal studies were carried out in material older than the Late Miocene at Section 210-29-CC. The Pleistocene to Late Miocene contains abundant to common and well to moderately well preserved planktonic foraminifera. However, because of the considerable depth of deposition (4643 meters), much dissolution has affected those planktonic foraminiferal tests not reworked from shallower water. Reworked assemblages are generally well preserved although characteristically highly sorted. Because of the reworking and dissolution, the planktonic foraminiferal biostratigraphy is not reliable.

\section{REGIONAL DISTRIBUTION PATTERNS}

The Late Cenozoic planktonic foraminiferal faunas of the southwest Pacific deep-sea drilling sites demonstrate distributional patterns that are clearly related to environmental differences throughout the area. Stratigraphic ranges of numerous species are obviously related to general differences in water masses between sites and water-mass fluctuations at each site in the past. Because the sites studied range from cool-subtropical (Site 207-207A) through warm subtropical (Sites 206 and 208) to tropical areas (Sites 209, 210, 203), a complex relationship is revealed between the evolution of species in various water masses, subsequent migration to other water masses, and environmental influences on their stratigraphic ranges and frequencies.

\section{Middle Miocene}

The Middle Miocene is best represented in the two warm subtropical sites (Sites 206 and 208). Important forms at both of these sites are Globigerina woodi, Globigerina nepenthes, Globorotalia mayeri, Globorotalia miozea conoidea, Sphaeroidinella seminulina, Globoquadrina altispira, Orbulina universa, and Globigerinoides quadrilobatus trilobus. Within the Middle Miocene, Globorotalia mayeri grades upward into Globorotalia continuosa with both forms being consistent throughout their respective ranges. It is important to note that the Middle Miocene faunas of the warm subtropical sites are similar to those of the cool subtropical site (Site 207-207A). Furthermore, even the tropical Middle Miocene fauna represented at Site 209 is similar to those further south except for the addition of Globorotalia menardii and Globorotalia siakensis. Thus, the Middle Miocene faunas of the region are rather uniform. This uniformity of planktonic foraminiferal faunas throughout the region decreases markedly in younger strata with increased biogeographic provincialism. Increasing provincialism probably reflects a narrowing of faunal belts after the Middle Miocene or an increasing tropical influence after the Middle Miocene due to northward drift of the Tasman Sea region associated with the Cenozoic northward drift of Australia.

\section{Late Miocene}

The Late Miocene is represented at four of the sites studied (Sites 207-207A, 206, 208, and 210), ranging from temperate to tropical. At Site 206 a disconformity has cut out the latest Miocene. Temperate faunas characteristically contain Globigerina nepenthes, Globigerina bulloides, Globigerina falconensis, Globigerina woodi, and Globigerina decoraperta throughout. G. woodi and G. decoraperta are particularly important elements in the Late Miocene and become much less dominant in the Pliocene (particularly Late Pliocene) and the Pleistocene, while G. bulloides and G. falconensis become more important. An important element in the early Late Miocene is Globorotalia continuosa. This species is replaced in the late Late Miocene by Globigerina pachyderma. An important and conspicuous evolutionary change within the upper Miocene is that from Globorotalia miozea conoidea to Globorotalia conomiozea. Both forms are consistent elements of the fauna throughout their respective ranges.

Further to the north is Site 206, which is the cooler of the two warm subtropical sites. The presence of Globigerinoides quadrilobatus sacculifer, Sphaeroidinella subdehiscens, and Globorotalia menardii in the Late Miocene reflects warmer conditions than the temperate faunas further south. Otherwise the faunas are rather similar.

Still further to the north within the warm subtropical region (Site 208), the cooler forms, Globigerina woodi and 


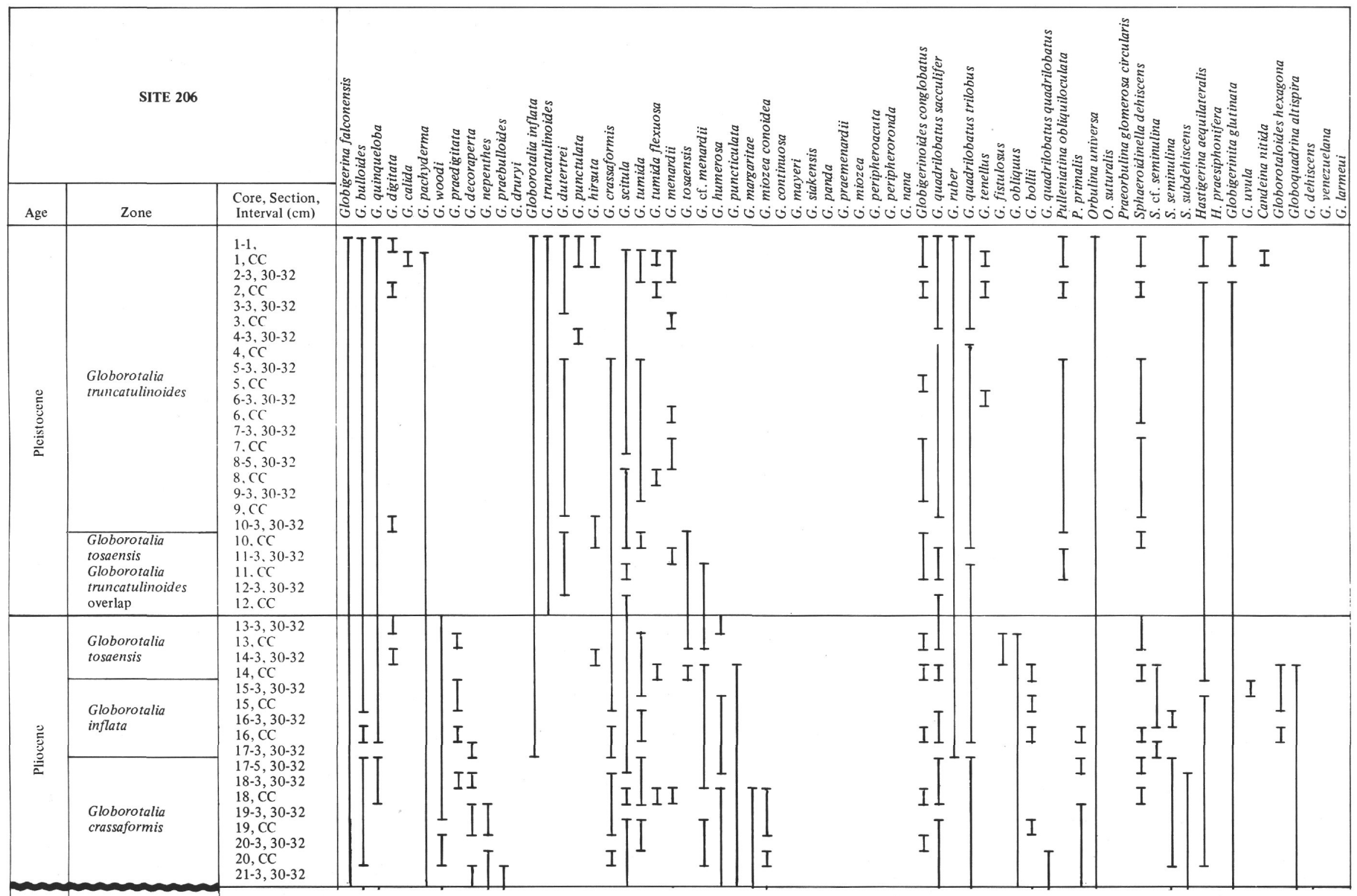

Figure 4. Distribution of planktonic foraminifera and zonation at Site 206. 


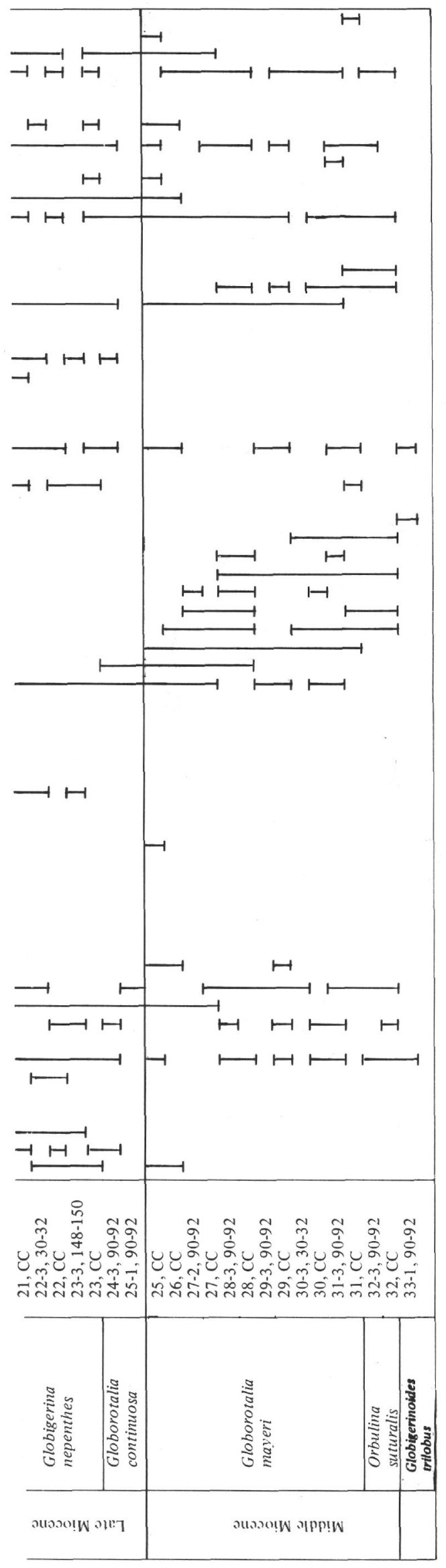

Globigerina bulloides, become less consistent; G. menardii becomes more important; and Globorotalia acostaensis appears. In addition, the presence of Globigerinoides quadrilobatus sacculifer, Pulleniatina primalis, Sphaeroidinella subdehiscens, Candeina nitida, Globoquadrina altispira, Globigerinoides obliquus, and Globigerinoides conglobatus reflects the warmer conditions at these latitudes.

In the tropical belt (Site 210) cool-water species such as Globigerina bulloides and Globigerina woodi are very rare. Instead the fauna is made up almost exclusively of abundant warm-water forms including Globorotalia menardii, Globorotalia tumida, Globigerinoides quadrilobatus sacculifier, and Pulleniatina primalis. Globorotalia conomiozea and other members of the G. "miozea" group that are typical of the cooler waters to the south are absent.

\section{Pliocene}

The Pliocene is well represented in Leg 21 material, occurring in all six sites examined. The temperate Pliocene fauna contains important G. woodi, G. falconensis, $G$. bulloides, and Globigerina pachyderma. Coiling direction changes in G. pachyderma reflect oscillations in water masses over the region during the Pliocene. The Late Pliocene is marked by increased frequencies of $G$. bulloides and $G$. falconensis and decreased frequencies of $G$. woodi and $G$. decoraperta. The Miocene-Pliocene boundary is marked by the evolutionary transition from Globorotalia conomiozea to Globorotalia puncticulata. G. puncticulata is an important element throughout the Early Pliocene in both temperate and warm subtropical areas and in turn evolves into Globorotalia inflata in the Late Pliocene in both areas. In the temperate site, warm-water forms such as Sphaeroidinella, Globorotalia tumida, Globorotalia margaritae, and Globorotalia cibaoensis are generally rare when present. Globorotalia tosaensis occurs only rarely in the late Pliocene.

Further to the north at Site 206, similar cooler-water forms prevail, although warm-water forms such as $G$. tumida, G. humerosa, G. sacculifer, S. dehiscens, and $S$. subdehiscens appear within their respective ranges. In addition G. margaritae is more common in the Early Pliocene.

The Pliocene at Site 208 contains even fewer cooler-water forms, while warm-water forms are more common within their respective ranges. Warm-water forms present include Globorotalia tumida, Globorotalia menardii, Globorotalia margaritae, Globorotalia humerosa, Globorotalia acostaensis, Globorotalia cibaoensis, Globigerinoides conglobatus, Pulleniatina primalis, Sphaeroidinella subdehiscens, and Sphaeroidinella seminulina. The evolution of G. crassaformis to G. tosaensis is recorded in the Late Pliocene of Site 208. G. tosaensis is more important in the warmer Pliocene sequences.

In the tropical Pliocene, G. puncticulata and G. inflata are virtually absent, while G. tumida, S. dehiscens, and $P$. primalis increase even more in importance. 


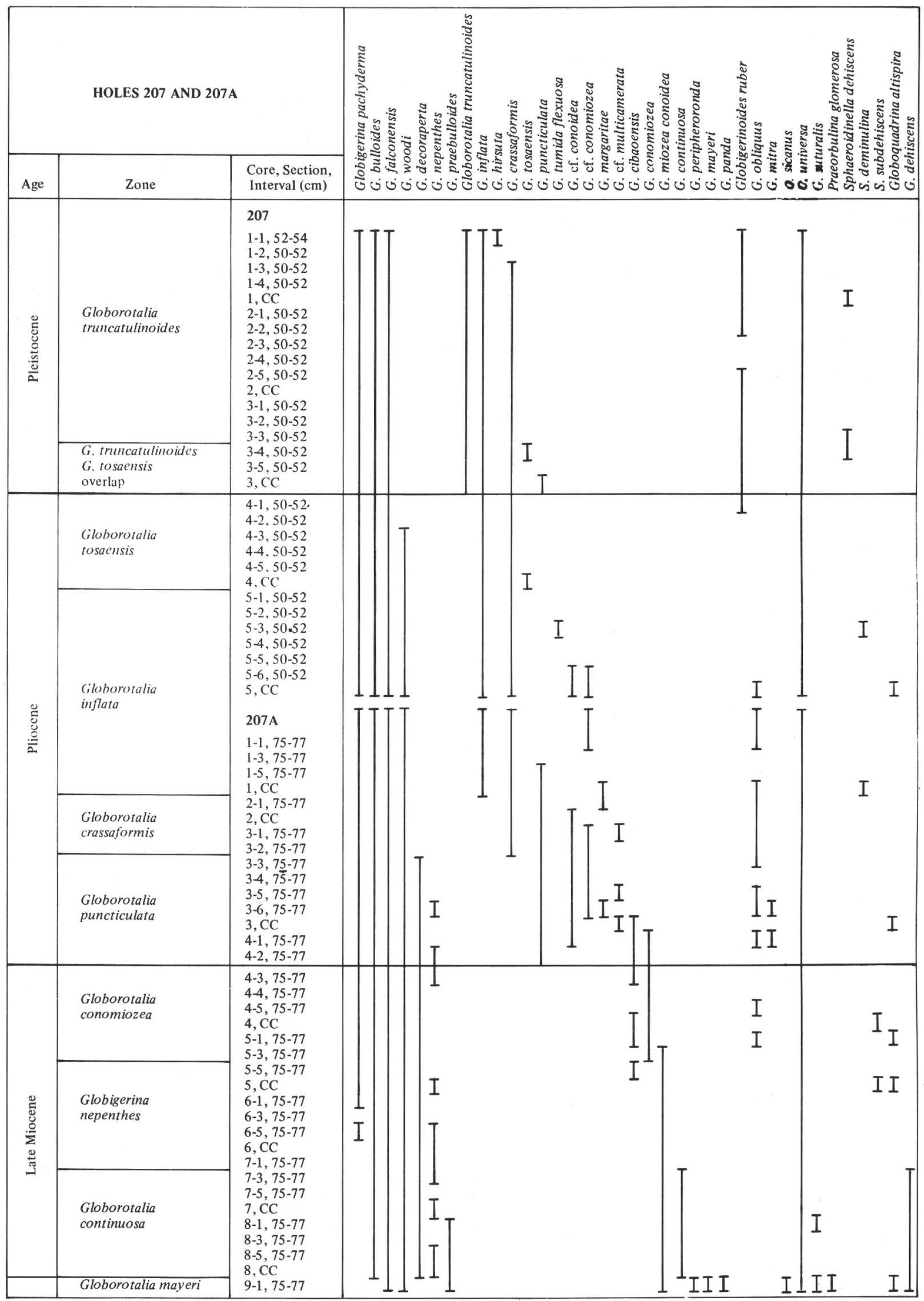

Figure 5. Distribution of planktonic foraminifera and zonation at Site 207-207A. 


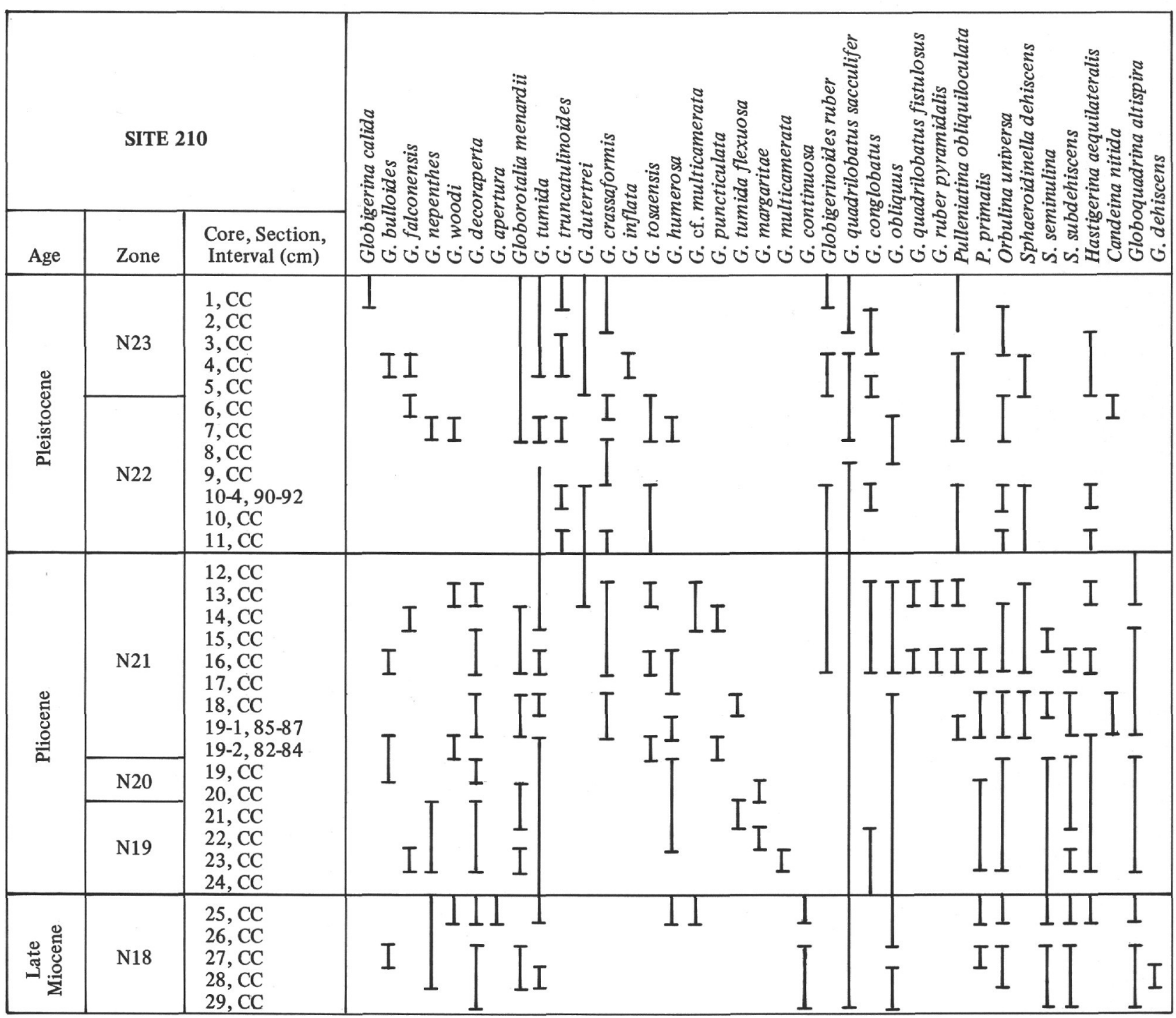

Figure 6. Distribution of planktonic foraminifera and zonation at Site 210.

\section{Pleistocene}

Important elements in the temperate faunas of the Pleistocene (Site 207-207A) include Globigerina bulloides, G. falconensis, and G. pachyderma, while G. crassaformis, $G$. truncatulinoides, and $O$. universa are consistently present. At these latitudes, fluctuations in coiling directions with G. pachyderma and large fluctuations in frequency of Globigerinoides ruber reflect large-scale fluctuations of the subtropical water mass. At this latitude, tropical and warm subtropical forms such as G. tumida, G. menardii, Sphaeroidinella, and Pulleniatina are absent or very rare.

Further to the north at Site 206, cooler forms are still dominant, although tropical forms such as G. tumida, $G$. menardii, $P$. obliquiloculata, and Sphaeroidinella are present in low frequencies at several intervals. $G$. pachyderma is represented almost exclusively by rightcoiling forms reflecting warmer conditions at these latitudes during the Pleistocene than in areas to the south.
In the warm subtropical Site 208, cooler forms are either greatly reduced or absent. G. pachyderma (right coiling) is very rare and $G$. bulloides is infrequent or rare. On the other hand, the tropical forms such as Sphaeroidinella dehiscens, Pulleniatina obliquiloculata, and Globorotalia tumida are more important. Alternations in relative abundance can be detected between the cooler forms $G$. inflata and $G$. falconensis and the warm forms G. tumida, G. menardii, and $P$. obliquiloculata. As in the Gulf of Mexico these alternations reflect interglacial-glacial episodes (Kennett and Huddlestun, 1972).

In the tropical sites, even $G$. inflata is virtually eliminated, while the usual tropical forms are overwhelmingly predominant.

\section{PLIOCENE-PLEISTOCENE BOUNDARY}

The Pliocene-Pleistocene boundary, in all of the Leg 21 sites examined, has been placed at the first appearance of 


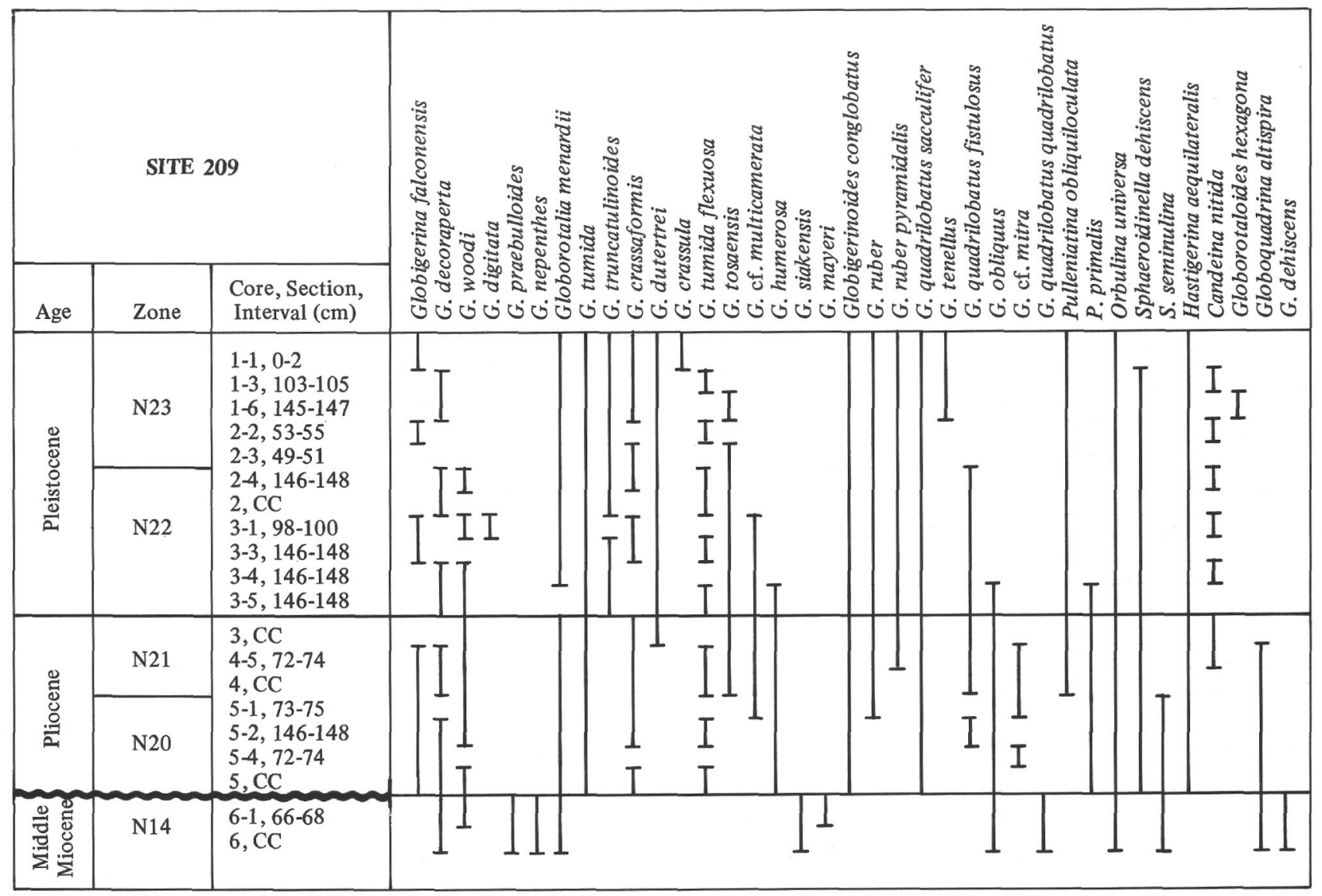

Figure 7. Distribution of planktonic foraminifera and zonation at Site 209.

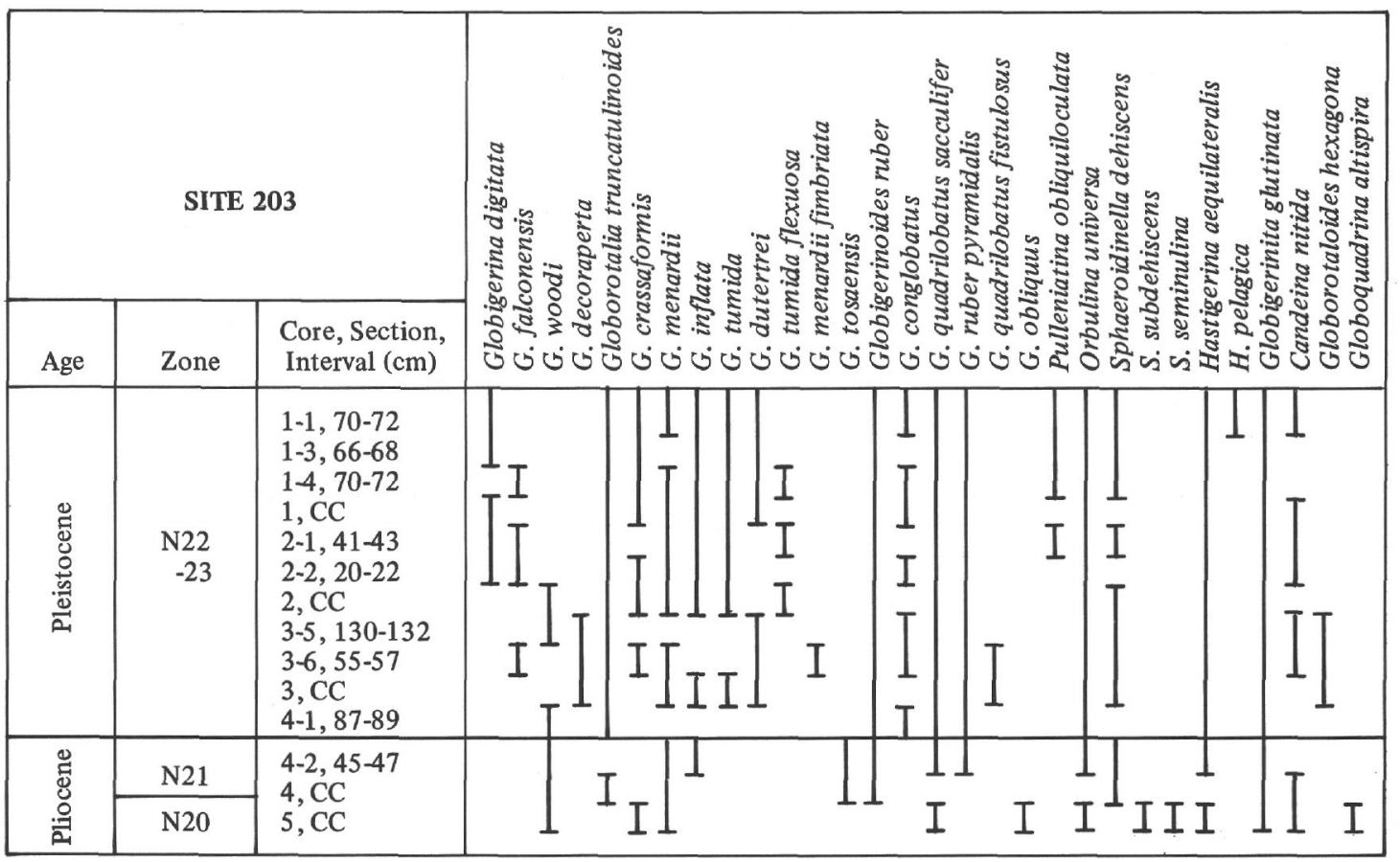

Figure 8. Distribution of planktonic foraminifera and zonation at Site 203. 
Globorotalia truncatulinoides (Figures 3 to 8), in approximate agreement with the first appearance of $G$. truncatulinoides within the type basal Pleistocene Calabrian Stage at Santa Maria Catanzaro in southern Italy (Bayliss, 1969). The first appearance of $G$. truncatulinoides and hence, the Plio-Pleistocene boundary in tropical deep-sea cores is associated with the major normal event in the Matuyama (Berggren et al., 1967; Phillips et al., 1968; Glass et al., 1967) which has been variously called the Olduvai (Opdyke, 1972) or the Gilsa (Watkins, 1972) the base of which is 1.79 m.y. B.P.

The southwest Pacific cores do not all exhibit a simple gradational bioseries like that described by Berggren et al. (1967). In Site 207 (cool subtropical), G. truncatulinoides appears abruptly and is continuously present throughout the Pleistocene, while $G$. tosaensis is very rare. No gradation was observed between $G$. tosaensis and $G$. truncatulinoides. Further to the north in Site 206 (warm subtropical), a fairly simple gradation occurs between $G$. tosaensis and $G$. truncatulinoides. The transition is dominated by rightcoiling forms.

In Site 208 the transition from $G$. tosaensis to $G$. truncatulinoides is not a simple gradational evolutionary change with steadily increasing abundances of the morphotype of $G$. truncatulinoides. Instead, the relative abundance of the two forms fluctuates significantly within the interval of overlap. In tropical Site 209, the interrelationship is even more complex. In this site, large fluctuations in the relative abundance of both forms occur throughout almost the entire interval of overlap of the two forms (from Cores 3-4 to 2-4). Alternations of G. tosaensis and $G$. truncatulinoides have also been described in a late Pliocene-Early Pleistocene core in the southwest Pacific (Kennett and Gietzenauer, 1969) and shown to be related to paleooceanographic oscillations. In summary, the evolution of $G$. truncatulinoides from $G$. tosaensis is complex with the two forms, at least in part related to particular oceanographic conditions in various water masses during the Plio-Pleistocene transition. Because of these complexities, it is possible that the earliest appearance of $G$. truncatulinoides was not simultaneous in various water masses.

\section{MIOCENE-PLIOCENE BOUNDARY}

The type Miocene-Pliocene boundary in Italy is at the boundary between the Late Miocene Messinian Stage and the overlying "trubi" Marl of the Zanclian Stage considered to be of Early Pliocene age. Blow (1969) found that the first appearance of Sphaeroidinella dehiscens, which marks the N18/N19 boundary, is 13 meters above the Miocene-Pliocene boundary in Italy. Furthermore, Cita (1973) considers that Globorotalia margaritae first appears slightly above the Miocene-Pliocene boundary in Mediterranean deep drilled sites and ranges to the upper part of the Early Pliocene.

Hays et al. (1969) discovered that $S$. dehiscens increases greatly in abundance within the Mammoth Reversed Event (3.0 m.y. B.P.) in tropical Pacific cores, although they show that it ranges as rare specimens throughout the Gilbert and lower Gauss epochs (approximately 5 to 3 m.y. B.P.). Bandy et al. (1971) treated the level of increased abundance of $S$. dehiscens as the $S$. dehiscens datum and correlated it with the N18/N19 boundary and the Miocene-Pliocene boundary, which they dated as 3.0 m.y. B.P. because of its relation to the Mammoth Event.

The ranges of $S$. dehiscens, $G$. margaritae, and other species such as Globorotalia puncticulata and Globorotalia crassaformis in the Leg 21 sites shed further light on the Miocene-Pliocene boundary problem. In these sites $G$. margaritae occurs earlier than $S$. dehiscens (Figures 3 to 8 ). In fact, the two species are mutually exclusive with $G$. margaritae in Sites 206, 208, and 210 occurring in the Early Pliocene and $S$. dehiscens appearing in the Middle Pliocene after the extinction of $G$. margaritae and ranging to the present day. Thus, the first appearance of $S$. dehiscens is later than in tropical north Pacific cores (Hays et al., 1969) and in the type Italian section (Blow, 1969) and, instead, reflects the level of widespread increased abundance that took place in the Middle Pliocene. The first appearance of $S$. dehiscens does not represent a true datum level because, like many species, its range varies between different water masses. It appears likely that the first appearance of $G$. margaritae represents a more reliable datum level, approximating the Miocene-Pliocene boundary over a wider range of water masses.

The relations between the Miocene-Pliocene boundary as used in the Leg 21 sites and the traditional position of the New Zealand Miocene-Pliocene boundary may also be considered. As previously mentioned, S. dehiscens is of no value in the correlation of the Miocene-Pliocene boundary in this area. In New Zealand the Miocene-Pliocene boundary has been placed between the Kapitean and Opoitian stages and is based on the first evolutionary appearance of nonkeeled Globorotalia variously called $G$. inflata (Jenkins, 1971); G. crassaformis (Kennett, 1966c); and G. puncticulata (Hornibrook and Edwards, 1971; Kennett and Watkins, 1972). I now consider the earliest form to be $G$. puncticulata. This form was derived in an evolutionary bioseries from $G$. conomiozea (previously called the $G$. crassaformis bioseries by Kennett, 1966c). This evolution is clearly shown in Site 207 by very abundant specimens. The Miocene-Pliocene boundary in this site has been placed at the first appearance of $G$. puncticulata (G. puncticulata also includes $G$. sphericomiozea, Walters) as in New Zealand (Kennett 1966a; b; c; 1967). In Site 207 G. margaritae has not been found lower than the first appearance of $G$. puncticulata and thus, no positive biostratigraphic evidence yet exists to indicate that the Miocene-Pliocene boundary in New Zealand is younger than the type boundary in Italy.

In Site 206 G. puncticulata, G. margaritae, and $G$. crassaformis appear together because of the presence of a disconformity that has eliminated the earliest Pliocene and latest Miocene biostratigraphic sequence. This core, thus, does not assist much in correlation of the Miocene-Pliocene boundary in different water masses.

In Site 208, the evolutionary bioseries from $G$. conomiozea to $G$. puncticulata is not represented. Instead, $G$. puncticulata appears later than the last appearance of $G$. conomiozea and the first appearance of $G$. margaritae 
(Figure 3). The first appearance of G. puncticulata in this site is considered to reflect later migration to warmer waters after its initial evolutionary appearance in cooler waters to the south. Thus, the Miocene-Pliocene boundary in Site 208 is placed at the first appearance of $G$. margaritae rather than $G$. puncticulata like that in the Mediterranean deep drilled sites (Cita, 1973). Furthermore, because the last appearance of $G$. conomiozea coincides with the first appearance of G. margaritae in Site 208, it appears that the New Zealand Miocene-Pliocene boundary is similar to that in Europe.

\section{PLANKTONIC FORAMINIFERAL ZONES}

\section{General}

As a result of the wide latitudinal spread of the DSDP Leg 21 sites in the southwest Pacific $\left(13^{\circ} 45^{\prime} \mathrm{S}\right.$ to $\left.36^{\circ} 57^{\prime} \mathrm{S}\right)$, sites were drilled in three distinct water-mass areas; cool subtropical (temperate); warm subtropical; and tropical. At present each of these areas is marked by fairly distinct planktonic foraminiferal assemblages. A trend towards a more and more restricted latitudinal distribution of many planktonic foraminiferal species began in the Late Eocene and Oligocene and became progressively more pronounced during the Miocene, Pliocene, and Pleistocene (Bolli, 1970). This distribution has led to the development of distinct Late Cenozoic zonations for the tropical areas (e.g., Bolli, 1970; Banner and Blow, 1965; Blow, 1969; Jenkins, 1972) and temperate areas (e.g., Jenkins, 1966; 1967). No zonal schemes have been established for areas intermediate between tropical and temperate. As a result, there has been great difficulty in correlating the zonal schemes between the two areas. During the progress of this work it was found that differences in stratigraphic ranges of important taxa in these various regimes meant that it was indeed necessary to establish a zonal scheme for the water mass between tropical and cool subtropical (temperate) regions which in this report is called the warm subtropical area.

Three zonal schemes have been utilized in this study. For the tropical sites the zonation of Banner and Blow (1965) and Blow (1969) has been utilized (Figures 6 to 8). The other two zonal schemes are new and are defined in this study. One of these has been established using the sites from the warm subtropical area (Figures 3,4, and 9), while the other has been established on the basis of stratigraphic ranges in Site 207-207A adjacent to northern New Zealand in cool subtropical conditions (Figures 5 and 10). The only planktonic foraminiferal zonation established for the Late Cenozoic of New Zealand is that of Jenkins $(1966 ; 1967)$. This zonation was found to be too broad for application to Leg 21 material. In particular, Jenkins established only one zone (Globorotalia inflata Zone) to encompass the entire Pliocene and Pleistocene, while a number of subzones were established on coiling direction changes in Globigerina pachyderma. Hornibrook and Edwards (1971) also have pointed out a series of foraminiferal and nannofossil datum levels for the Late Cenozoic of New Zealand. Figure 11 shows the correlation between the two new zonal schemes with the zonal scheme of Jenkins $(1967 ; 1971)$ and the New Zealand Middle-Late Cenozoic stages.
In defining these two new zonal schemes, an attempt has been made to utilize species with similar ranges in both the warm and cool subtropical areas. As a result, the zonations are quite similar (Figure 11), although it is important to note that differences do exist in the definition of several of the zones with the same names. For example, the Globorotalia tosaensis Zone (Figure 11) in the warmer subtropical areas is defined at the first evolutionary appearance of G. tosaensis from Globorotalia crassaformis. In the cooler subtropical area this species has less consistent occurrence throughout its range because of cooler water conditions. Furthermore, its evolution from $G$. crassaformis is not represented. Hence, the base of the zone is determined in one case on the first evolutionary appearance and in the other case by its first cryptogenetic appearance. It is possible that additional work may demonstrate that the base of the zone is indeed equivalent in both areas. Another example involves the Globorotalia puncticulata zones in both areas. In cooler subtropical areas the evolution of $G$. puncticulata from Globorotalia conomiozea is clear and widespread (Kennett, 1966c), and the base of the $G$. puncticulata Zone is marked by the first evolutionary appearance of $G$. puncticulata. In the warmer subtropical area, the evolutionary bioseries is not represented, and the first appearance of G. puncticulata occurs later than the extinction of G. conomiozea and the first appearance of the Early Pliocene form Globorotalia margaritae. Hence, the base of the zone is different in age in the two areas.

By far the most useful forms for zonation of the Late Cenozoic in this area are species of Globorotalia because they evolved rapidly, are usually common and consistent elements of the planktonic foraminiferal faunas, and in some cases evolutionary changes transgress both the cool and warm subtropical areas. In the Late Miocene to Late Pliocene cool subtropical area a continuous evolutionary lineage proceeds from Globorotalia miozea conoidea (previously G. miozea of Kennett, 1966c) to $G$. conomiozea to $G$. puncticulata (previously G. crassaformis of Kennett, 1966c) to G. inflata. This lineage forms the foundation of the Late Miocene to Pliocene zonation.

The summary of correlations of the zones between each site is shown in Figure 12.

\section{Zonal Characteristics}

Warm Subtropical Planktonic Foraminiferal Zones

\section{Globorotalia truncatulinoides Zone}

Definition:

Top: Not defined, but the zone includes all faunas above the extinction of Globorotalia tosaensis Takayangi and Saito.

Base: Extinction of Globorotalia tosaensis Takayangi and Saito.

Age: Late Pleistocene-Recent.

Taxa:

Extinctions within zone:

Globorotalia tumida flexuosa 


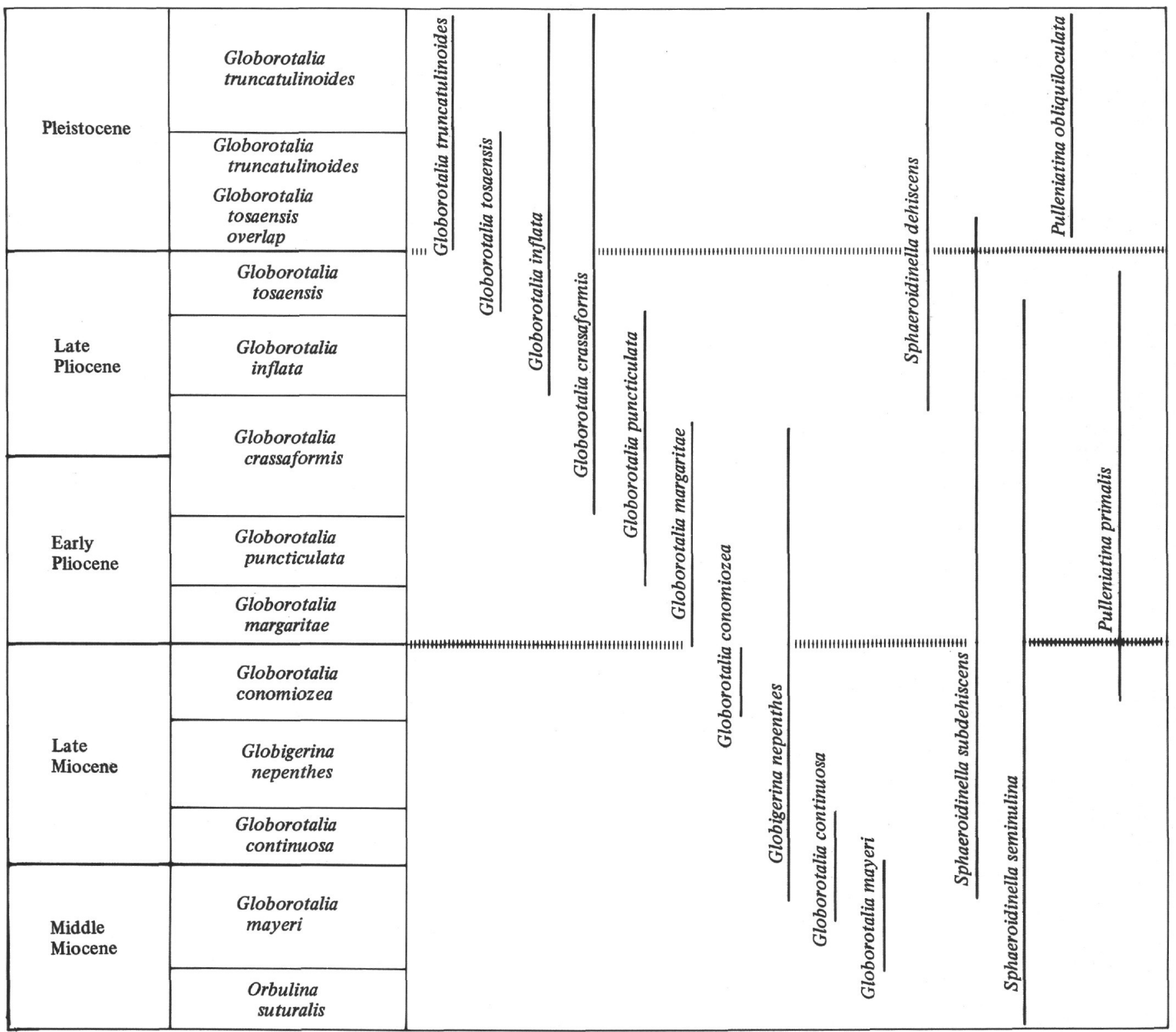

Figure 9. Range distribution of key planktonic foraminifera in the warm-subtropical deep-sea sequences of the southwest Pacific.

Initial appearances within zone:

Globigerinoides tenellus

Important species ranging throughout zone:

Candeina nitida

Globigerina falconensis

G. bulloides

Globorotalia

truncatulinoides

G. inflata

G. crassaformis

G. tumida

G. menardii

Reference Section: Site 208: $26^{\circ} 06.61^{\prime} \mathrm{S}, 161^{\circ} 13.27^{\prime} \mathrm{E}$.
Occurrence of Zone: Continuously cored at Sites 206 and 208.

Correlation: Broadly equivalent to the uppermost part of Zone N22 and including N23 (Banner and Blow, 1965; Blow, 1969) and to N22 of Parker (1967). Broadly equivalent to the upper part of $G$. truncatulinoides truncatulinoides Zone (Bolli, 1970) and the upper part of Pulleniatina obliquiloculata Zone (Jenkins, 1972).

\section{Globorotalia truncatulinoides-Globorotalia tosaensis Overlap Zone}

Definition:

Top: Extinction of Globorotalia tosaensis Takayangi and Saito. 


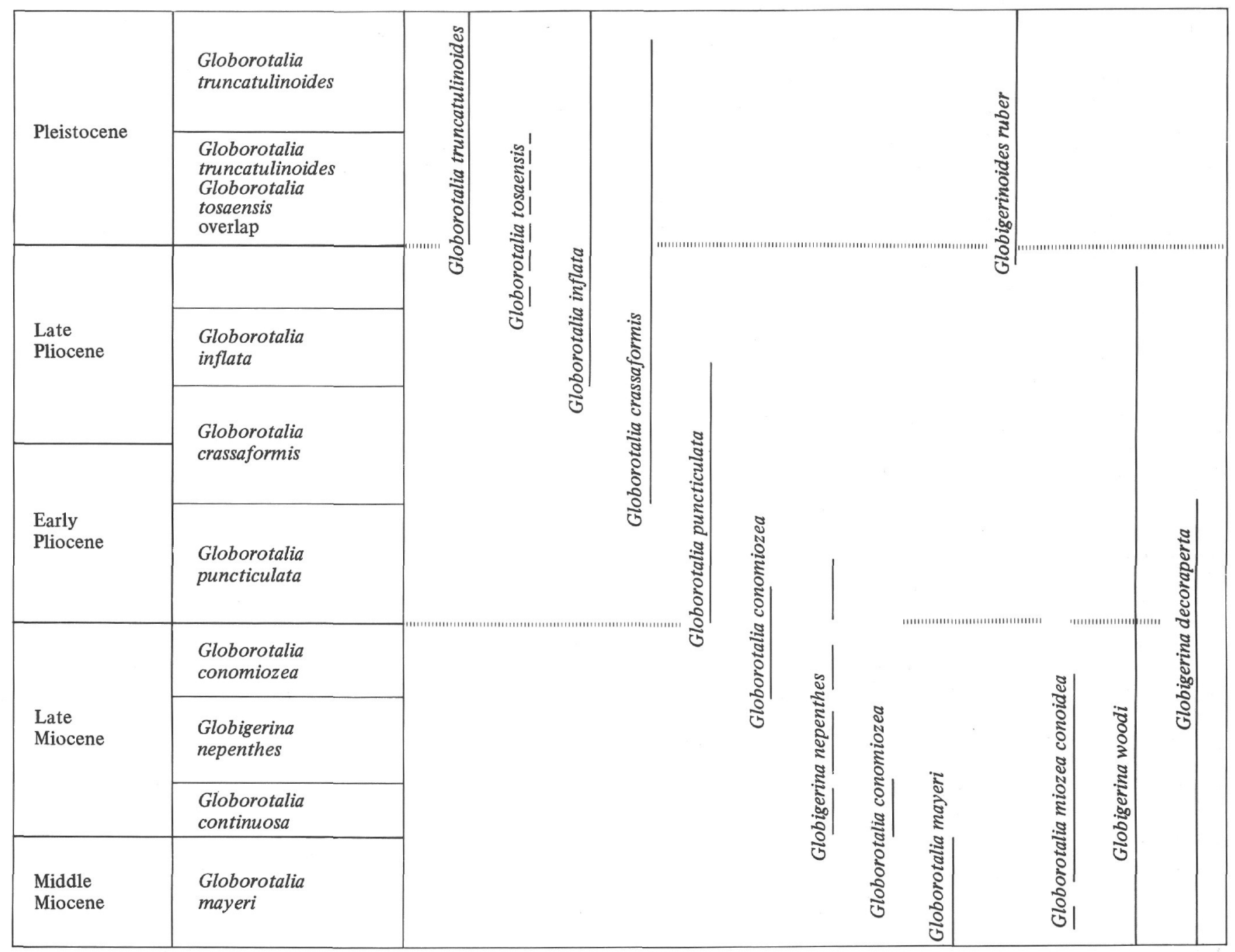

Figure 10. Range distribution of key planktonic foraminifera in the cool-subtropical deep-sea sequence (Site 207-207A) in the southwest Pacific.

Base: Initial evolutionary appearance of Globorotalia truncatulinoides (d'Orbigny). (First appearance of morphotype)

Age: Early Pleistocene.

Taxa:

Extinctions within zone:

Globigerina woodi

Globorotalia humerosa

Globorotalia cf. multicamerata

Globigerinoides quadrilobatus fistulosus

Globigerinoides obliquus

Sphaeroidinella subdehiscens

Initial appearances within zone:

Globorotalia dutertrei

Pulleniatina obliquiloculata
Important species ranging throughout zone:
Globigerina falconensis
Globigerinoides ruber
G. bulloides
$G$. conglobatus
Globorotalia inflata
G. crassaformis
G. truncatulinoides
G. quadrilobatus trilobus
Orbulina universa
G. tosaensis
Sphaeroidinella dehiscens Hastigerina aequilateralis

Reference Section: Site 208: $26^{\circ} 06.61^{\prime} \mathrm{S}, 161^{\circ} 13.27^{\prime} \mathrm{E}$.

Occurrence of Zone: Continuously cored at Sites 206 and 208.

Correlation: Broadly equivalent to Zone N22 (Banner and Blow, 1965; Blow, 1969) and to the lower part of N22 of Parker (1967). Broadly equivalent to the lower part of $G$. truncatulinoides truncatulinoides Zone (Bolli, 1970) and the lower part of Pulleniatina obliquiloculata Zone (Jenkins, 1972). 


\begin{tabular}{|c|c|c|c|c|}
\hline \multirow[b]{2}{*}{ Age } & \multicolumn{2}{|c|}{ DSDP Leg 21} & \multirow{2}{*}{$\begin{array}{l}\text { New } \\
\text { Zealand } \\
\text { Zones } \\
\text { (Jenkins, 1971) }\end{array}$} & \multirow[b]{2}{*}{$\begin{array}{l}\text { New } \\
\text { Zealand } \\
\text { Stages }\end{array}$} \\
\hline & $\begin{array}{l}\text { Warm Subtropical } \\
\text { Planktonic } \\
\text { Foraminiferal } \\
\text { Zones }\end{array}$ & $\begin{array}{c}\text { Cool Subtropical } \\
\text { Planktonic } \\
\text { Foraminiferal } \\
\text { Zones }\end{array}$ & & \\
\hline \multirow[b]{2}{*}{ Pleistocene } & $\begin{array}{l}\text { Globorotalia } \\
\text { truncatulinoides }\end{array}$ & $\begin{array}{l}\text { Globorotalia } \\
\text { truncatulinoides }\end{array}$ & & \\
\hline & $\begin{array}{l}\text { Globorotalia } \\
\text { truncatulinoides } \\
\text { Globorotalia } \\
\text { tosaensis } \\
\text { overlap }\end{array}$ & $\begin{array}{l}\text { Globorotalia } \\
\text { truncatulinoides } \\
\text { Globorotalia } \\
\text { tosaensis } \\
\text { overlap }\end{array}$ & & \\
\hline \multirow{3}{*}{$\begin{array}{l}\text { Late } \\
\text { Pliocene }\end{array}$} & $\begin{array}{l}\text { Globorotalia } \\
\text { tosaensis }\end{array}$ & $\begin{array}{l}\text { Globorotalia } \\
\text { tosaensis }\end{array}$ & \multirow{6}{*}{$\begin{array}{l}\text { Globorotalia } \\
\text { inflata }\end{array}$} & \multirow{6}{*}{ Opoitian } \\
\hline & $\begin{array}{l}\text { Globorotalia } \\
\text { inflata }\end{array}$ & $\begin{array}{l}\text { Globorotalia } \\
\text { inflata }\end{array}$ & & \\
\hline & Globorotalia & Globorotalia & & \\
\hline \multirow{3}{*}{$\begin{array}{l}\text { Early } \\
\text { Pliocene }\end{array}$} & cravoug or tints & crasurajotions & & \\
\hline & $\begin{array}{l}\text { Globorotalia } \\
\text { puncticulata }\end{array}$ & \multirow{2}{*}{$\begin{array}{l}\text { Globorotalia } \\
\text { puncticulata }\end{array}$} & & \\
\hline & $\begin{array}{c}\text { Globorotalia } \\
\text { margaritae }\end{array}$ & & & \\
\hline \multirow{3}{*}{$\begin{array}{l}\text { Late } \\
\text { Miocene }\end{array}$} & $\begin{array}{l}\text { Globorotalia } \\
\text { conomiozea }\end{array}$ & $\begin{array}{c}\text { Globorotalia } \\
\text { conomiozea }\end{array}$ & $\begin{array}{l}\text { Globorotalia } \\
\text { miozea } \\
\text { sphericomiozea }\end{array}$ & Kapitean \\
\hline & $\begin{array}{c}\text { Globigerina } \\
\text { nepenthes }\end{array}$ & $\begin{array}{r}\text { Globigerina } \\
\text { nepenthes }\end{array}$ & \multirow{2}{*}{$\begin{array}{c}\text { Globorotalia } \\
\text { miotumida } \\
\text { miotumida }\end{array}$} & \multirow{2}{*}{$\begin{array}{l}\text { Tonga- } \\
\text { porutuon }\end{array}$} \\
\hline & $\begin{array}{c}\text { Globorotalia } \\
\text { continuosa }\end{array}$ & $\begin{array}{r}\text { Globorotalia } \\
\text { continuosa }\end{array}$ & & \\
\hline \multirow[t]{2}{*}{$\begin{array}{l}\text { Middle } \\
\text { Miocene }\end{array}$} & $\begin{array}{l}\text { Globorotalia } \\
\text { mayeri }\end{array}$ & $\begin{array}{l}\text { Globorotalia } \\
\text { mayeri }\end{array}$ & $\begin{array}{l}\text { Globorotalia } \\
\text { mayeri } \\
\text { mayeri }\end{array}$ & \multirow{2}{*}{$\begin{array}{l}\text { Waiauan - } \\
\text { Lillburnian }\end{array}$} \\
\hline & $\begin{array}{l}\text { Orhulina } \\
\text { suturalis }\end{array}$ & & $\begin{array}{l}\text { Orbulina } \\
\text { suturalis }\end{array}$ & \\
\hline $\begin{array}{l}\text { Early } \\
\text { Miocene }\end{array}$ & $\begin{array}{l}\text { Globigerinoides } \\
\text { trilobus }\end{array}$ & & & \\
\hline
\end{tabular}

Figure 11. Correlation of Leg 21 cool-subtropical and warm-subtropical foraminiferal zones.

\section{Globorotalia tosaensis Zone}

Definition:

Top: Initial evolutionary appearance of Globorotalia truncatulinoides (d'Orbigny). (First appearance of morphotype.)

Base: Initial evolutionary appearance of Globorotalia tosaensis Takayanagi and Saito.

Age: Late Pliocene.
Taxa:

Extinctions within zone:

Globorotalia puncticulata

Pulleniatina primalis

Globoquadrina altispira

Important species ranging throughout zone:

Globigerina falconensis
G. bulloides
G. woodi
G. quadrilobatus sacculifer
G. quadrilobatus trilobus

Globigerinoides ruber 


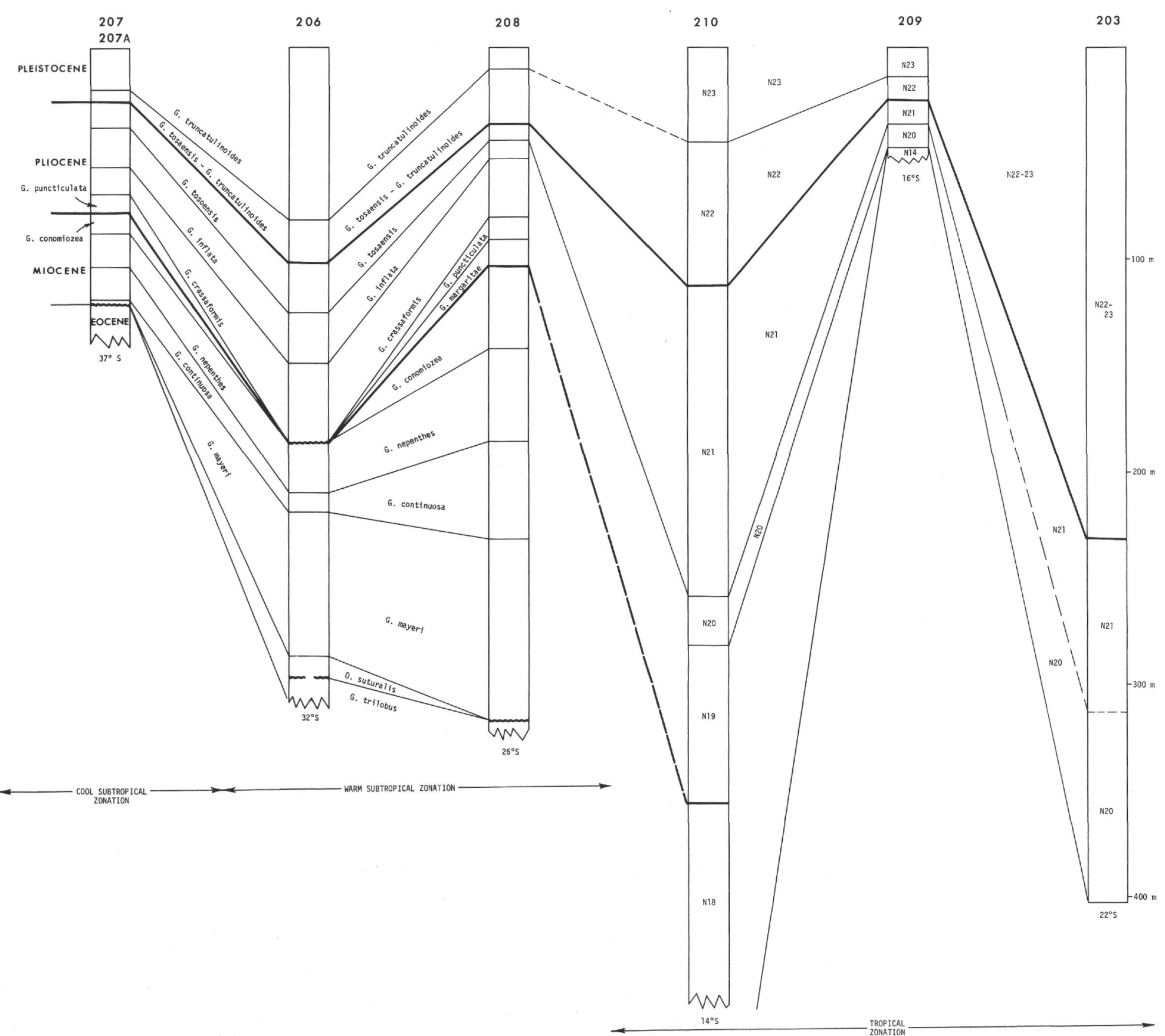


Globorotalia inflata

G. crassaformis

G. tosaensis

G. tumida

Reference Section: Site 208: $26^{\circ} 06.61^{\prime} \mathrm{S}, 161^{\circ} 13.27^{\prime} \mathrm{E}$.

Occurrence of Zone: Continuously cored at Sites 206 and 208.

Correlation: Equivalent to Zone N21 (Banner and Blow, 1965; Blow, 1969; Parker, 1967). Equivalent to Globorotalia truncatulinoides tosaensis Zone of Bolli (1970).

\section{Globorotalia inflata Zone}

Definition:

Top: Initial evolutionary appearance of Globorotalia tosaensis Takayanagi and Saito.

Base: Initial evolutionary appearance of Globorotalia inflata (d'Orbigny).

Age: Late Pliocene.

Taxa:

Extinctions within zone:

Globigerina decoraperta

Sphaeroidinella seminulina

Initial appearances within zone:

Globigerinoides quadrilobatus fistulosus

Important species ranging throughout zone:
Globigerina falconensis
G. quadrilobatus sacculifer
G. bulloides
G. quadrilobatus trilobus
G. woodi
G. obliquus
Globorotalia crassaformis
G. inflata
G. tumida
Pulleniatina primalis
Orbulina universa
Sphaeroidinella dehiscens
G. humerosa
S. subdehiscens
S. seminulina
Globigerinoides ruber
G. conglobatus
Hastigerina aequilateralis
Globoquadrina altispira

Reference Section: Site 208: $26^{\circ} 06.61^{\prime} \mathrm{S}, 161^{\circ} 13.27^{\prime} \mathrm{E}$.

Occurrence of Zone: Continuously cored at Sites 206 and 208.

\section{Globorotalia crassaformis Zone}

Definition:

Top: Initial evolutionary appearance of Globorotalia inflata (d'Orbigny).

Base: Initial appearance of Globorotalia crassaformis (Galloway and Wissler).

Age: Early-Late Pliocene.
Taxa:

Extinctions within zone:

Globigerina nepenthes

Globorotalia acostaensis

G. cibaoensis

G. margaritae

G. cf. miozea conoidea

Initial appearances within zone:

Globigerinoides ruber

Sphaeroidinella dehiscens as consistent element

Important species ranging throughout zone:

Globigerina falconensis

G. bulloides

Pulleniatina primalis

G. woodi

G. decoraperta

Globorotalia tumida

G. crassaformis

G. humerosa

Globigerinoides conglobatus

G. quadrilobatus sacculifer

G. quadrilobatus trilobus

G. obliquus

Reference Section: Site 208: $26^{\circ} 06.61^{\prime} \mathrm{S}, 161^{\circ} 13.27^{\circ} \mathrm{E}$.

Occurrence of Zone: Continuously cored at Sites 206 and 208. At Site 206 the base of the zone is a disconformity, and the base of the zone may be missing.

Correlation: Includes the upper part of Globorotalia margaritae Zone and lower part of Globorotalia exilis/ Globorotalia miocenica Zone of Bolli (1970). Includes upper part of N19 of Banner and Blow (1965), Blow (1969), and Parker (1967).

\section{Globorotalia puncticulata Zone}

Definition:

Top: Initial appearance of Globorotalia crassaformis (Galloway and Wissler).

Base: Initial appearance of Globorotalia puncticulata (Deshayes) (not evolutionary).

Age: Early Pliocene.

Taxa:

Initial appearance within zone:

Globorotalia humerosa

Important species ranging throughout zone:
Globigerina falconensis
G. bulloides
G. woodi
G. decoraperta
G. nepenthes
Globigerinoides quadrilobatus sacculifer
G. quadrilobatus trilobus
G. obliquus
Pulleniatina primalis 

Globorotalia tumida
G. menardii
G. cf. miozea conoidea
G. puncticulata
G. cibaoensis

Reference Section: Site 208: $26^{\circ} 06.61^{\prime} \mathrm{S}, 161^{\circ} 13.27^{\prime} \mathrm{E}$.

Occurrence of Zone: Continuously cored at Site 208, missing in disconformity at Site 206.

Correlation: Includes part of N19 of Banner and Blow (1965), Blow (1969), and Parker (1967) and part of Globorotalia margaritae Zone of Bolli (1970).

\section{Globorotalia margaritae Zone}

Definition:

Top: Initial appearance of Globorotalia puncticulata (Deshayes) (not evolu tionary).

Base: Initial appearance of Globorotalia margaritae Bolli and Bermudez.

Age: Early Pliocene.

Taxa:

Extinctions within zone:

Globigerina praebulloides

Orbulina suturalis

Initial appearances within zone:

Globigerina digitata

Globorotalia tumida

G. tumida flexuosa

G. margaritae

Important species ranging throughout zone:

$\begin{array}{ll}\text { Globigerina falconensis } & \text { G. quadrilobatus sacculifer } \\ \text { G. woodi } & \text { G. quadrilobatus trilobus } \\ \text { G. decoraperta } & \text { G. obliquus } \\ \text { G. nepenthes } & \text { Pulleniatina primalis } \\ \text { Globorotalia menardii } & \text { Orbulina universa } \\ \text { G. cf. multicamerata } & \text { Sphaeroidinella subdehiscens } \\ \text { G. acostaensis } & \text { S. seminulina } \\ \text { G. cf. miozea conoidea } & \text { Hastigerina aequilateralis } \\ \text { Globigerinoides conglobatus } & \text { Globoquadrina altispira }\end{array}$

Reference Section: Site 208: $26^{\circ} 06.61^{\prime} \mathrm{S}, 161^{\circ} 13.27^{\prime} \mathrm{E}$.

Occurrence of Zone: Continuously cored at Site 208, missing in disconformity at Site 206.

Correlation: Includes lower part of N19 of Banner and Blow (1965), Blow (1969), and Parker (1967) and lower part of Globorotalia margaritae Zone of Bolli (1970).

\section{Globorotalia conomiozea Zone}

Definition:

Top: Initial appearance of Globorotalia margaritae Bolli and Bermudez.

Base: Initial evolutionary appearance of Globorotalia conomiozea Kennett.

Age: Late Miocene.

Taxa:

Initial Appearance within zone:

Pulleniatina primalis

Important species ranging throughout zone:

G. bulloides

$G$. nepenthes

Globorotalia menardii

G. acostaensis

$G$. cf. miozea conoidea

G. conomiozea
Globigerina falconensis
Globigerinoides quadrilobatus sacculifer
G. quadrilobatus trilobus
G. obliquus
Orbulina universa
O. suturalis
Sphaeroidinella subdehiscens
$S$. seminulina
Hastigerina aequilateralis
Globoquadrina altispira

Reference Section: Site 208: $26^{\circ} 06.61^{\prime} \mathrm{S}, 161^{\circ} 13.27^{\prime} \mathrm{E}$.

Occurrence of Zone: Continuously cored at Site 208, missing in disconformity at Site 206.

Correlation: Broadly equivalent to Zone N18 (Banner and Blow, 1965; Blow, 1969; Parker, 1967) and to Globorotalia dutertrei Zone of Bolli (1970). Equivalent to Globorotalia miozea sphericomiozea Zone of Jenkins (1971).

\section{Globigerina nepenthes Zone}

Definition:

Top: Initial evolutionary appearance of Globorotalia conomiozea Kennett.

Base: Extinction of Globorotalia continuosa Blow.

Age: Late Miocene.

Taxa:

Initial appearances within zone:

Globigerina pachyderma

Globorotalia cf. multicamerata

Candeina nitida

Important species ranging throughout zone:

Globigerina falconensis Orbulina universa

G. woodi

O. suturalis

G. nepenthes

Globorotalia menardii

G. miozea conoidea

G. acostaensis

Globigerinoides quadrilobatus sacculifer

Sphaeroidinella subdehiscens

S. seminulina

Hastigerina aequilateralis

Globoquadrina altispira

G. dehiscens

G. quadrilobatus trilobus

G. obliquus

Reference Section: Site $208: 26^{\circ} 06.61^{\prime} \mathrm{S}, 161^{\circ} 13.27^{\prime} \mathrm{E}$.

Occurrence of Zone: Continuously cored at Sites 206 and intermittently cored at Site 208. At Site 206 the top of the zone is a disconformity, and the top of the zone may be missing. 
Correlation: Broadly equivalent to Zone N17 (Banner and Blow, 1965; Blow, 1969; Parker, 1967) and partly equivalent to Globorotalia acostaensis Zone of Bolli (1970). Broadly equivalent to Globorotalia plesiotumida Zone of Jenkins (1972) and upper part of Globorotalia miotumida miotumida Zone of Jenkins (1971).

\section{Globorotalia continuosa Zone}

Definition:

Top: Extinction of Globorotalia continuosa Blow

Base: Extinction of Globorotalia mayeri Cushman and Ellisor.

Age: Late Miocene.

Taxa:

Initial appearances within zone:

Globigerinoides quadrilobatus sacculifer

G. obliquus

Important species ranging throughout zone:

Globigerina falconensis Orbulina universa

G. woodi

G. nepenthes

Globorotalia menardii

G. miozea conoidea

Globigerinoides

quadrilobatus trilobus

Reference Section: Site 208: $26^{\circ} 06.61^{\prime} \mathrm{S}, 161^{\circ} 13.27^{\prime} \mathrm{E}$.

Occurrence of Zone: Continuously cored at Site 206 and intermittently cored at Site 208 .

Correlation: Broadly equivalent to the lower part of Globorotalia miotumida miotumida Zone of Jenkins (1971).

\section{Globorotalia mayeri Zone}

Definition:

Top: Extinction of Globorotalia mayeri Cushman and Ellisor.

Base: Initial evolutionary appearance of Globorotalia mayeri Cushman and Ellisor.

Age: Middle Miocene

Taxa:

Extinctions within zone:

Globorotalia siakensis

G. panda

G. praemenardii

G. miozea

G. peripheroronda

G. peripheracuta

Praeorbulina glomerosa circularis.

Initial appearances within zone:

Globorotalia miozea conoidea
Orbulina universa

Sphaeroidinella subdehiscens

Important species ranging throughout zone:

Globigerina woodi

G. decoraperta

Globorotalia mayeri

Orbulina universa

Globigerinoides quadrilobatus trilobus

Sphaeroidinella seminulina

Globoquadrina altispira

G. dehiscens

Reference Section: Site 208: $26^{\circ} 06.61^{\prime} \mathrm{S}, 161^{\circ} 13.27^{\prime} \mathrm{E}$.

Occurrence of Zone: Continuously cored at Site 206 and intermittently cored at Site 208. At Site 208 the base of the zone is a disconformity, and the base of the zone may be missing.

Correlation: Equivalent to Globorotalia mayeri mayeri Zone of Jenkins (1971).

\section{Orbulina suturalis Zone}

Definition:

Top: Initial evolutionary appearance of Globorotalia mayeri Cushman and Ellisor.

Base: Because of a possible disconformity at Site 206, the base of the zone could not be defined. It is likely that additional work will show that the base of the zone is best placed at the extinction of Praeorbulina glomerosa curva as in the New Zealand Miocene zonation (Jenkins, 1971).

Age: Middle Miocene.

Taxa:

Important species ranging throughout zone:

Globigerina woodi Orbulina suturalis

Globorotalia siakensis Praeorbulina glomerosa

G. panda circularis

G. miozea

G. peripheroronda Sphaeroidinella seminulina Globoquadrina altispira

Reference Section: Site $206: 32^{\circ} 00.75^{\prime} \mathrm{S}, 165^{\circ} 27.15^{\prime} \mathrm{E}$.

Occurrence of zone: Continuously cored at Site 206. Missing in disconformity at Site 208. At Site 206 the base of the zone is possibly a disconformity, and the base of the zone is not represented.

Correlation: Equivalent to Orbulina suturalis Zone of Jenkins (1971).

\section{Globigerinoides trilobus Zone}

Not formerly designated. The zone is assumed to be equivalent to the Globigerinoides trilobus Zone of Jenkins (1971), the top of which is defined at the initial evolutionary appearance of Praeorbulina. 


\section{J. P. KENNETT}

Cool Subtropical Planktonic Foraminiferal Zones

\section{Globorotalia truncatulinoides Zone}

\section{Definition:}

Top: Not defined, but the zone includes all faunas above the extinction of Globorotalia tosaensis Takayanagi and Saito.

Base: Extinction of Globorotalia tosaensis Takayanagi and Saito.

Age: Late Pleistocene-Recent.

Taxa:

Important species ranging throughout zone:

Globigerina pachyderma G. inflata

G. bulloides G. crassaformis

G. falconensis Globigerinoides ruber

Globorotalia truncatulinoides Orbulina universa

Reference Section: Site 207: $36^{\circ} 57.75^{\prime} \mathrm{S}, 165^{\circ} 26.06^{\prime} \mathrm{E}$.

Occurrence of Zone: Continuously cored at Site 207.

Correlation: Equivalent to the Globorotalia truncatulinoides Zone in sites of DSDP Leg 21 from the warm subtropical region (Figure 11).

\section{Globorotalia truncatulinoides-Globorotalia tosaensis Overlap Zone}

Definition:

Top: Extinction of Globorotalia tosaensis Takayanagi and Saito.

Base: Initial evolutionary appearance of Globorotalia truncatulinoides (d'Orbigny). (First appearance of morphotype.)

Age: Early Pleistocene

Taxa:

Important species ranging throughout zone:

Globigerina pachyderma

G. inflata

G. bulloides

G. crassaformis

G. falconensis

Globorotalia

Globigerinoides ruber

truncatulinoides

Reference Section: Site 207: $36^{\circ} 57.75^{\prime} \mathrm{S}, 165^{\circ} 26.06^{\prime} \mathrm{E}$.

Occurrence of Zone: Continuously cored at Site 207.

Correlation: Equivalent to the Globorotalia truncatulinoides-Globorotalia tosaensis Overlap Zone in sites of Leg 21 from the warm subtropical region (Figure 11).

\section{Globorotalia tosaensis Zone}

\section{Definition:}

Top: Initial appearance of Globorotalia truncatulinoides (d'Orbigny). (First appearance of morphotype).

Base: Initial appearance of Globorotalia tosaensis Takayanagi and Saito.
Age: Late Pliocene

Taxa:

Extinction within zone:

Globigerina woodi

Initial appearance within zone:

Globigerinoides ruber

Important species ranging throughout zone:

Globigerina falconensis Globorotalia inflata

G. bulloides

G. falconensis

G. crassaformis

Orbulina universa

Reference Section: Site 207: $36^{\circ} 57.75^{\prime} \mathrm{S}, 165^{\circ} 26.06^{\prime} \mathrm{E}$.

Occurrence of Zone: Continuously cored at Site 207.

Correlation: Broadly equivalent to the Globorotalia tosaensis Zone in sites of Leg 21 from the warm subtropical region (Figure 11). Exact definition differs, however, because $G$. tosaensis is rare as the result of cooler oceanographic conditions, and the first appearance of both $G$. tosaensis and $G$. truncatulinoides were not observed as evolutionary appearances.

\section{Globorotalia inflata Zone}

Definition:

Top: Initial appearance of Globorotalia tosaensis Takayanagi and Saito.

Base: Initial evolutionary appearance of Globorotalia inflata (d'Orbigny).

Age: Late Pliocene.

Taxa: Extinctions within zone:

Globorotalia cf. miozea conoidea

$G$. cf. conomiozea

Globigerinoides obliquus

Sphaeroidinella seminulina

Globoquadrina altispira

Important species ranging throughout zone:

Globigerina pachyderma

Globorotalia inflata

$G$. bulloides

G. falconensis

G. crassaformis

G. woodi

Orbulina universa

Reference Section: Site 207 (upper part) and 207A (lower part): $36^{\circ} 57.75^{\prime} \mathrm{S}, 165^{\circ} 26.06^{\prime} \mathrm{E}$

Occurrence of Zone: Continuously cored at Site 207-207A

Correlation: Broadly equivalent to Globorotalia inflata Zone in sites of Leg 21 from the warm subtropical region (Figure 11). Exact definition of top of zone differs because the first appearance of $G$. tosaensis at Site 207 does not necessarily coincide with the initial evolutionary appearance as observed in Sites 206 and 208. 


\section{Globorotalia crassaformis Zone}

Definition:

Top: Initial evolutionary appearance of Globorotalia inflata (d'Orbigny).

Base: Initial appearance of Globorotalia crassaformis (Galloway and Wissler).

Age: Early-Late Pliocene.

Taxa:

Important species ranging throughout zone:

Globigerina pachyderma

G. puncticulata

G. bulloides

G. falconensis

G. woodi

Globorotalia crassaformis

Reference Section: Site 207A: $36^{\circ} 57.75^{\prime} \mathrm{S}, 165^{\circ} 26.06^{\prime} \mathrm{E}$.

Occurrence of Zone: Continuously cored at Site 207A.

Correlation: Equivalent to Globorotalia crassaformis Zone in sites of Leg 21 from the warm subtropical region (Figure 11).

\section{Globorotalia puncticulata Zone}

Definition:

Top: Initial appearance of Globorotalia crassaformis (Galloway and Wissler).

Base: Initial evolutionary appearance of Globorotalia puncticulata (Deshayes).

Age: Early Pliocene.

Taxa:

Extinctions within zone:

Globigerina decoraperta

G. nepenthes

Globorotalia cibaoensis

G. conomiozea

Important species ranging throughout zone:

Globigerina falconensis Globorotalia puncticulata

G. bulloides

G. woodi

G. cf. miozea conoidea

Orbulina universa

Reference Section: Site 207A: $36^{\circ} 57.75^{\prime} \mathrm{S}, 165^{\circ} 26.06^{\prime} \mathrm{E}$.

Occurrence of Zone: Continuously cored at Site 207A.

Correlation: Equivalent to both the Globorotalia margaritae and Globorotalia puncticulata Zones in sites of Leg 21 from the warm subtropical region (Figure 11). It is important to note that the Globorotalia puncticulata Zones in both these areas are distinct. Globorotalia puncticulata in Site 207A first appears in evolutionary succession from Globorotalia conomiozea while in warmer waters to the north this species appears later and not in evolutionary succession. The base of the zone is thus diachronous.

\section{Globorotalia conomiozea Zone}

Definition:

Top: Initial evolutionary appearance of Globorotalia puncticulata (Deshayes).

Base: Initial evolutionary appearance of Globorotalia conomiozea Kennett.

Age: Late Miocene.

Taxa:

Extinction within zone:

Globorotalia miozea conoidea

Initial appearance within zone:

Globigerinoides obliquus

Important species ranging throughout zone:

Globigerina pachyderma Globorotalia conomiozea

G. bulloides

Orbulina universa

G. falconensis

Reference Section: Site 207A: $36^{\circ} 57.75^{\prime} \mathrm{S}, 165^{\circ} 26.06^{\prime} \mathrm{E}$.

Occurrence of Zone: Continuously cored at Site 207A.

Correlation: Equivalent to the Globorotalia miozea sphericomiozea Zone of Jenkins (1971). Broadly equivalent to the Globorotalia conomiozea Zone in sites of Leg 21 from the warm subtropical region (Figure 11).

\section{Globorotalia continuosa Zone}

Definition:

Top: Extinction of Globorotalia continuosa Blow.

Base: Extinction of Globorotalia mayeri Cushman and Ellisor.

Age: Late Miocene.

Taxa:

Extinction within zone:

Orbulina suturalis

Important species ranging throughout zone:

Globigerina bulloides Globorotalia miozea conoidea

$G$. falconensis

G. continuosa

G. woodi

Orbulina universa

G. decoraperta

Globoquadrina dehiscens

Reference Section: Site 207A: $36^{\circ} 57.75^{\prime} \mathrm{S}, 165^{\circ} 26.06^{\prime} \mathrm{E}$.

Occurrence of Zone: Continuously cored at Site 207A.

Correlation: Equivalent to the Globorotalia continuosa Zone in sites of Leg 21 from the warm subtropical region (Figure 11). Broadly equivalent to the lower part of the Globorotalia miotumida miotumida Zone of Jenkins (1971). 
Globigerina nepenthes Zone

Definition:

Top: Initial evolutionary appearance of Globorotalia conomiozea Kennett.

Base: Extinction of Globorotalia continuosa Blow.

Age: Late Miocene.

Taxa:

Extinction within zone:

Globoquadrina dehiscens

Initial appearance within zone:

Globigerina pachyderma

Important species ranging throughout zone:

Globigerina bulloides G. decoraperta

G. falconensis Globorotalia miozea conoidea

G. woodi

Orbulina universa

Reference Section: Site 207A: $36^{\circ} 57.75^{\prime} \mathrm{S}, 165^{\circ} 26.06^{\prime} \mathrm{E}$.

Occurrence of Zone: Continuously cored at Site 207A.

Correlation: Equivalent to the Globigerina nepenthes Zone in sites of Leg 21 from the warm subtropical region (Figure 11). Broadly equivalent to the upper part of Globorotalia miotumida miotumida Zone of Jenkins (1971).

\section{Globorotalia mayeri Zone}

Definition:

Top: Extinction of Globorotalia mayeri Cushman and Ellisor.

Base: Initial evolutionary appearance of Globorotalia mayeri Cushman and Ellisor.

Age: Middle Miocene.

Taxa:

Extinctions within zone:

Globorotalia peripheroronda

G. panda

Praeorbulina glomerosa circularis

Important species occurring within zone:

Globigerina falconensis Orbulina universa

G. woodi

O. suturalis

G. praebulloides Globoquadrina dehiscens

Globorotalia miozea conoidea

Reference Section: Site $207 \mathrm{~A}: 36^{\circ} 57^{\prime} \mathrm{S}, 165^{\circ} 26.06^{\prime} \mathrm{E}$.

Occurrence of Zone: Continuously cored at Site 207A.

Correlation: Equivalent to Globorotalia mayeri mayeri Zone of Jenkins (1971). Equivalent to the upper part of Globorotalia mayeri Zone in sites of Leg 21 from the warm subtropical region (Figure 11).
Tropical Planktonic Foraminiferal Zones

Late Cenozoic foraminiferal biostratigraphy was examined in three sites $(210,209,203)$ in the tropical region. At two of these sites (209 and 203) the Late Cenozoic is represented by only the Pleistocene and Pliocene. In Site 210 stratigraphic ranges of planktonic foraminifera were examined from the Late Miocene to the present day. The planktonic foraminiferal zonation of Banner and Blow (1965) and Blow (1969) is suitable for biostratigraphic subdivision of these sites (Figures 6 to 8 and 11 and 12). Although no detailed discussion is made here of the biostratigraphy of the tropical sites, the following conclusions have been made.

Pleistocene

1) The Pleistocene is marked by fairly consistent occurrence of Globorotalia truncatulinoides.

2) The early Pleistocene differs from the late Pleistocene by containing Globigerinoides quadrilobatus fistulosus (in Sites 203 and 209); Globorotalia tosaensis (in Sites 209 and 210); and Globigerina woodi (in Sites 203, 209, and 210).

3) The range of Globorotalia dutertrei approximates the Pleistocene, although in Site 210 this species extends from the latest Pliocene to the present day (upper part of N21 to present day).

\section{Pliocene}

1) The Late Pliocene Zone N21 is marked by the occurrence of $G$. tosaensis and the absence of $G$. truncatulinoides.

2) Pulleniatina obliquiloculata does not extend lower than the base of N21 (Late Pliocene) in the three sites.

3) Globoquadrina altispira becomes extinct at or near the Pliocene-Pleistocene boundary, and in none of the sections does this species overlap with Globorotalia truncatulinoides. The extinction of Globigerinoides obliquus is also close to the Pliocene-Pleistocene boundary.

4) Globigerinoides ruber ranges from the uppermost part of N20 to the Recent.

5) Pulleniatina primalis overlaps with $P$. obliquiloculata within Zone N21 (Late Pliocene) in Sites 209 and 210. P. primalis was not observed in Site 203.

6) In Site 210, the first appearance of Sphaeroidinella dehiscens and Globorotalia crassaformis occurs near the base of N21 (Late Pliocene). Despite solution concentration in Site $210, S$. dehiscens was not observed in the Early Pliocene.

7) The presence of Globorotalia margaritae marks the Early Pliocene in Site 210 where $S$. dehiscens is not present. $G$. margaritae appears to be a much more reliable indicator for the Early Pliocene than $S$. dehiscens, particularly in cooler areas away from the equator.

8) In Site 210, the Miocene-Pliocene boundary is difficult to place, but is tentatively placed at the extinction of Globorotalia continuosa and before the first appearance of $G$. margaritae. 


\section{ACKNOWLEDGMENTS}

The cooperation of Dr. R. E. Burns and Dr. J. E. Andrews, co-chief scientists for Leg 21, in obtaining excellent biostratigraphic sequences is greatly appreciated. Thanks also to A. R. Edwards and P. Dumitrica for valuable discussions. Ms. Trudy Wood prepared many samples during the cruise. I am also indebted to Ms. Charlotte Brunner for diverse technical assistance during this investigation. This work was partially supported by U.S. National Science Foundation Grant GA-35252.

The photographs of planktonic foraminifera were taken with the Cambridge S4 scanning electron microscope at the University of Rhode Island with the assistance of a grant from the National Science Foundation (Oceanography Division; GA-28905). The SEM was operated by Mr. D. Scales. Thanks also to Dr. P. Vella for suggesting useful changes to the manuscript.

\section{REFERENCES}

Bandy, O. L., Casey, R. E., and Wright, R. C., 1971. Late Neogene planktonic zonation magnetic reversals, and radiometric dates, Antarctic to tropics: Am. Geophys. Un. Ant. Res. Ser. 15, 1-26.

Banner, F. T. and Blow, W. H., 1965. Progress in the planktonic foraminiferal biostratigraphy of the Neogene: Nature, v. p. 1164.

Bayliss, D. D., 1969. The distribution of Hyalinea balthica and Globorotalia truncatulinoides in the type Calabrian: Lethaia, v. 2 , p. 133-143.

Berggren, W. A., Phillips, J. D., Bertels, A., and Wall, D., 1967. Late Pliocene-Pleistocene stratigraphy in deep-sea cores from the south-central North Atlantic: Nature, v. 216 , p. 253-255.

Blow, W. H., 1969. Late middle Eocene to Recent planktonic foraminiferal biostratigraphy: Plank. Microfossils, 1st Intern. Conf. (Geneva), p. 199.

Bolli, H. M., 1970. The foraminifera of Sites 23-31: Initial Reports of the Deep Sea Drilling Project, Volume IV. Washington (U.S. Government Printing Office), p. 577.

Cita, M. B., 1973. Pliocene biostratigraphy and chronostratigraphy: Initial Reports of the Deep Sea Drilling Project, Volume XIII. Washington (U.S. Government Printing Office), p. 1343.

Hays, J. D., Saito, T., Opdyke, N. D., and Burckle, L. H., 1969. Pliocene-Pleistocene sediments of the equatorial Pacific: their paleomagnetic, biostratigraphic, and climatic record: Geol. Soc. Am., Bull, v. 80, p. 1481.

Hornibrook, N.de B. and Edwards, A. R., 1971. Integrated planktonic foraminiferal and calcareous nannoplankton datum levels in the New Zealand Cenozoic: Proc. II Plankt. Conf., v. 2, p. 649.

Jenkins, D. G., 1966. Planktonic foraminiferal zones and new taxa from the Danian to Lower Miocene of New Zealand: New Zealand J. Geol. Geophys., v. 8, p. 1088. 1967. Planktonic foraminiferal zones and new taxa from the lower Miocene to the Pleistocene of New Zealand: New Zealand J. Geol. Geophys., v. 10, p. 1064. 1971. New Zealand Cenozoic Planktonic Foraminifera: New Zealand Geol. Surv. Paleont. Bull., v. $42,278 \mathrm{p}$.

1972. Planktonic foraminiferal biostratigraphy of the eastern equatorial Pacific DSDP Leg 9: Initial Reports of the Deep Sea Drilling Project, Volume IX. Washington (U.S. Government Printing Office), p. 1059.

Kennett, J. P., 1966a. Biostratigraphy and paleoecology in Upper Miocene - Lower Pliocene sections in Wairarapa and Southern Hawkes Bay: Roy. Soc. New Zealand, v. 4, p. 83 .

1966b. Four Upper Miocene to Lower Pliocene sections, Hawkes Bay to East Cape, N.Z: Trans. Roy. Soc. New Zealand, v. 4, p. 189.

1966c. The Globorotalia crassaformis bioseries in north Westland and Marlborough, New Zealand: Micropaleontology, v. 12, p. 235.

1967. Recognition and correlation of the Kapitean Stage (Upper Miocene) New Zealand: New Zealand J. Geol. Geophys., v. 10, p. 1051.

Kennett, J. P. and Geitzenauer, K. R., 1969. The Pliocene-Pleistocene boundary in a South Pacific deep-sea core: Nature, v. 224, p. 899.

Kennett, J. P. and Huddlestun, P., 1972. Late Pleistocene paleoclimatology, foraminiferal biostratigraphy and tephrochronology, western Gulf of Mexico: Quat. Res., v. 2, p. 38 .

Kennett, J. P. and Watkins, N. D., 1972. The biostratigraphic, climatic and paleomagnetic record of Late Miocene to Early Pleistocene sediments in New Zealand: Intern. Geol. Congress 24th (Montreal), p. 538.

Opdyke, N. D., 1972. Paleomagnetism of deep-sea cores: Rev. Geophys. Space Phys., v. 10, p. 213.

Parker, F. L., 1967. Late Tertiary biostratigraphy (planktonic foraminifera) of tropical Indo-Pacific deepsea cores: Am Paleontol. Bull., v. 52, 208 p.

Phillips, J. D., Berggren, W. A., Bertels, A., and Wall, D., 1968. Paleomagnetic stratigraphy and micropaleontology of three deep-sea cores from the central North Atlantic Ocean. Earth Planet. Sci. Rev., v. 4, p. 118.

Watkins, N. D., 1972. Review of the development of the geomagnetic polarity time scale and discussion of prospects for its finer definition: Geol. Soc. Am. Bull., v. 83, p. 551 . 


\section{PLATE 1}

Figures 1-4 Candeina nitida d'Orbigny, side views.

1. 21-206-1, CC; $\times 67$.

2. $21-208-9, \mathrm{CC} ; \times 73$.

3. 21-208-13-5, 50-52 cm; $\times 82$.

4. 21-208-13-5, 50-52 cm; $\times 82$.

Figures 5,6 Globigerina pachyderma (Ehrenberg), left coiling form. 5. Umbilical view; $\times 165$.

6. 21-207-4-1, 50-52 cm; Spiral view; $\times 158$.

Figures 7-11 Globigerina pachyderma (Ehrenberg), right coiling form.

7. Umbilical view; $\times 148$.

8. Spiral view; $\times 147$.

9. Umbilical view; $\times 171$.

10. Umbilical view; $X 152$.

11. 21-206-18, CC; Side view; $\times 152$.

Figures 12-14 Globigerina bulloides d'Orbigny.

12. Umbilical view; $\times 111$.

13. 21-206-14, CC; Spiral view; $\times 147$.

14. 21-207A-10-2, 75-77 cm; Umbilical view; $X 58$. 
PLATe 1
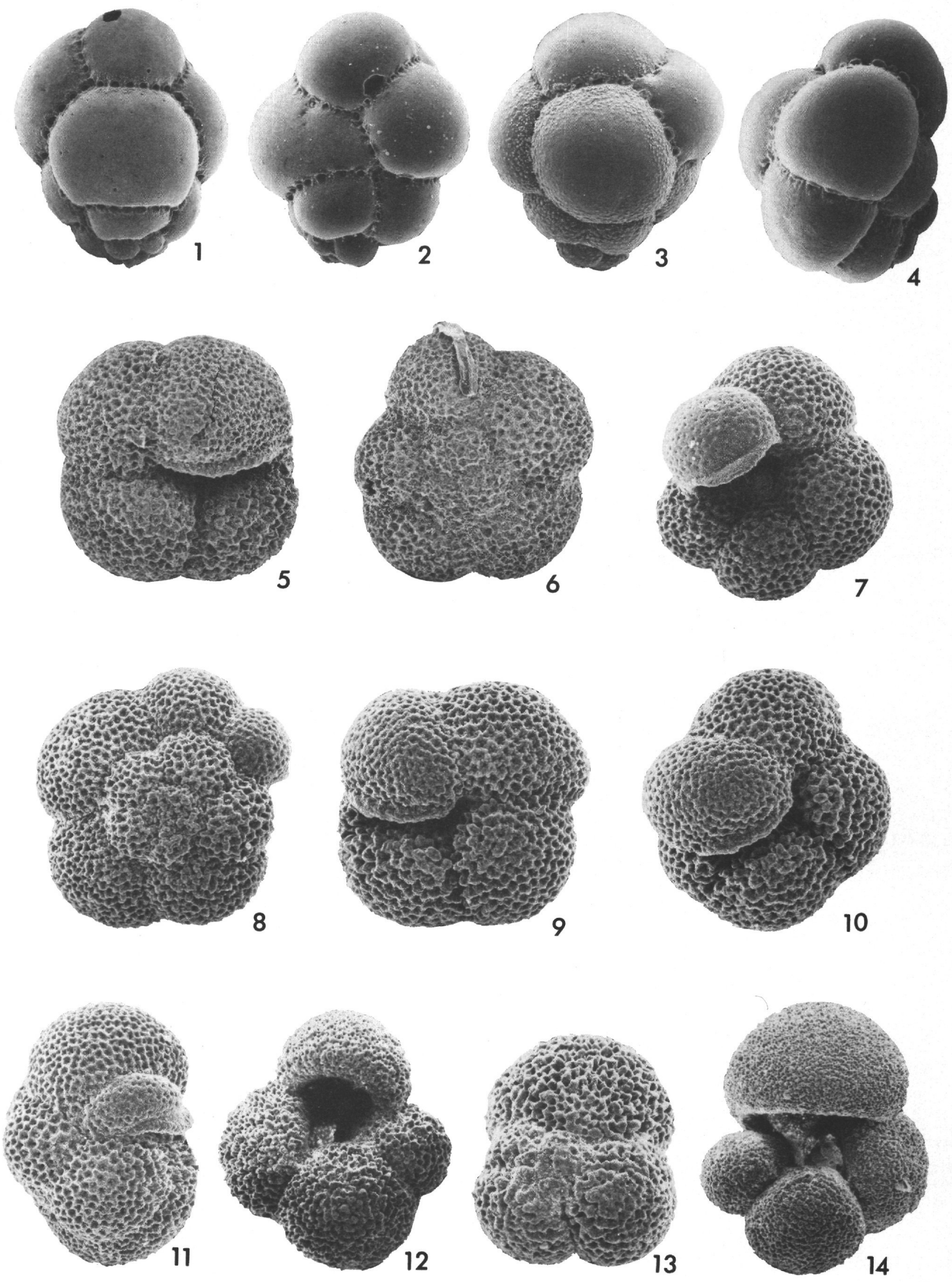


\section{PLATE 2}

Figure 1 Globigerina sp., 21-207A-10-2, 75-77 cm; Umbilical view; $\times 86$.

Figure 2 Globorotalia obesa Bolli; 21-208-20-2, $50-52 \mathrm{~cm}$; Umbilical view; $\times 69$.

Figures 3, $4 \quad$ Globigerina falconensis Blow.

3. Umbilical view; $\times 127$.

4. 21-206-12-3, 30-32 cm; Spiral view; $X 130$.

Figures 5-8 Globigerina woodi Jenkins.

5. 21-206-14, CC; Umbilical view; $X 179$.

6. 21-206-23, CC; Spiral view; $\times 132$.

7. 21-206-23, CC; Umbilical view; $X 166$.

8. 21-206-27, CC; Umbilical view; $\times 136$.

Figures 9, 10 Globigerina decoraperta Takayanagi and Saito.

9. Umbilical view; $\times 200$.

10. 21-207A-7, CC; Spiral view; $\times 175$.

Figures 11-14 Globigerina nepenthes Todd.

11. Umbilical view; $\times 141$.

12. 21-206-21, CC; Umbilical view; $X 132$.

13. Umbilical view, $X 133$.

14. 21-206-24, CC; Spiral view; $X 135$.

Figures 15, 16 Globigerina druryi Akers.

15. 21-206-28, CC; Umbilical view; $\times 140$.

16. 21-206-25, CC; Spiral view; $X 143$. 
PLATE 2
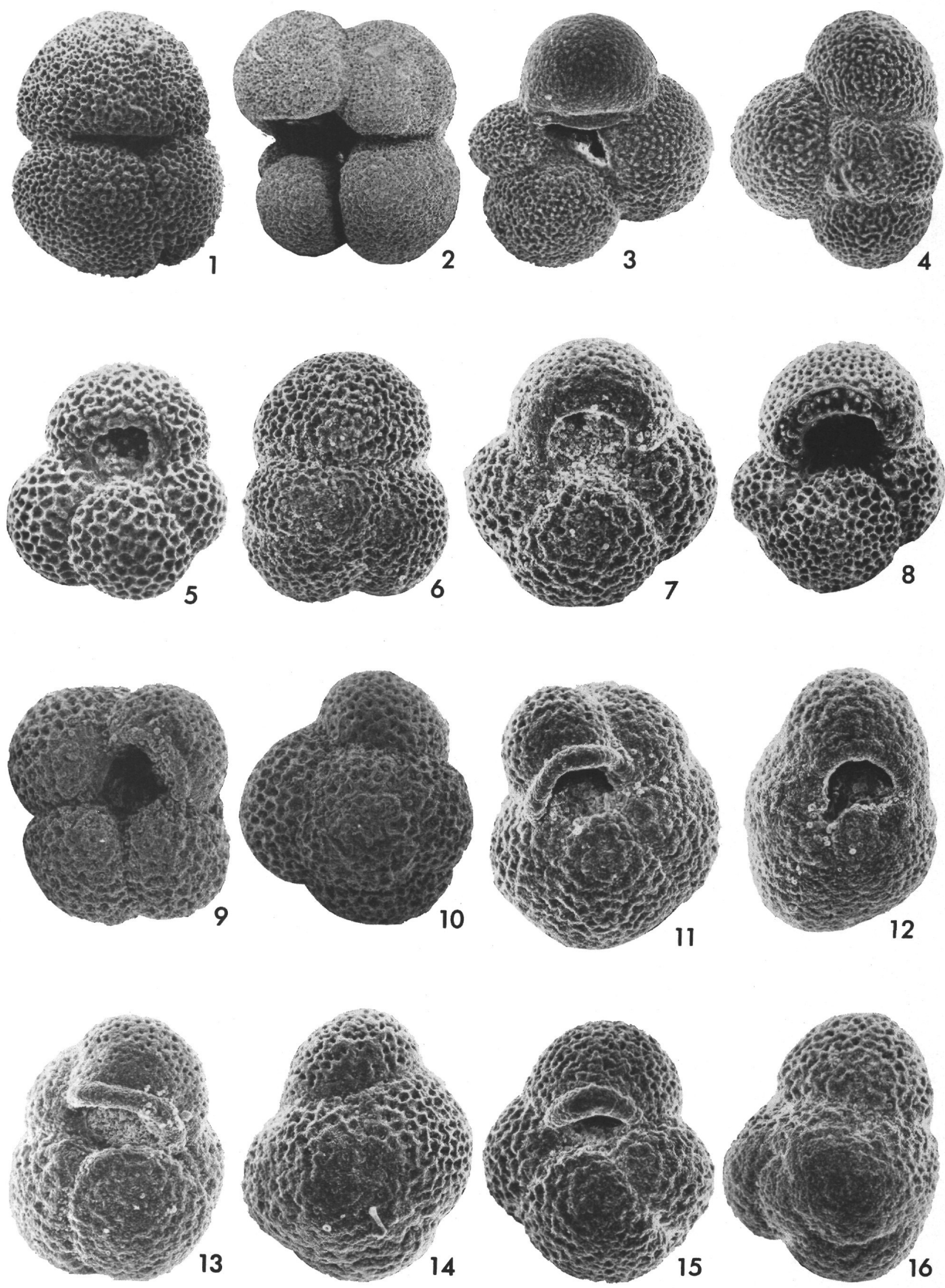


\section{PLATE 3}

Figures 1-3 Globoquadrina altispira (Cushman and Jarvis).

1. Umbilical view; $\times 98$.

2. Spiral view; $\times 106$.

3. 21-206-18, CC; Side view; $\times 108$.

Figures 4, $5 \quad$ Globigerina digitata Brady.

4. Umbilical view; $\times 106$.

5. 21-206-13, CC; Spiral view; $\times 111$.

Figure 6 Globigerina praedigitata Parker. 21-208-13-5; 50-53 $\mathrm{cm}$; Umbilical View; $X 111$.

Figures 7-9 Globigerina angulisuturalis Bolli.

7. Spiral view; $\times 211$.

8. Umbilical view; $\times 183$.

9. 21-209-13, CC; Spiral view; X202.

Figure $10 \quad$ Globigerinoides bolli Blow. 21-206-18, CC; Umbilical view; $\times 187$.

Figures 11, 13 Globigerinoides obliquus Bolli.

11. 21-206-13, CC; Spiral view; $X 60$.

13. 21-206-13, CC; Umbilical view; $\times 62$.

Figures 12,14,15 Globigerinoides conglobatus (Brady).

12. 21-206-7, CC; Spiral view; $X 71$.

14. 21-209-1, CC; Umbilical view; $X 63$.

15. 21-206-14, CC; Umbilical view; $\times 60$. 

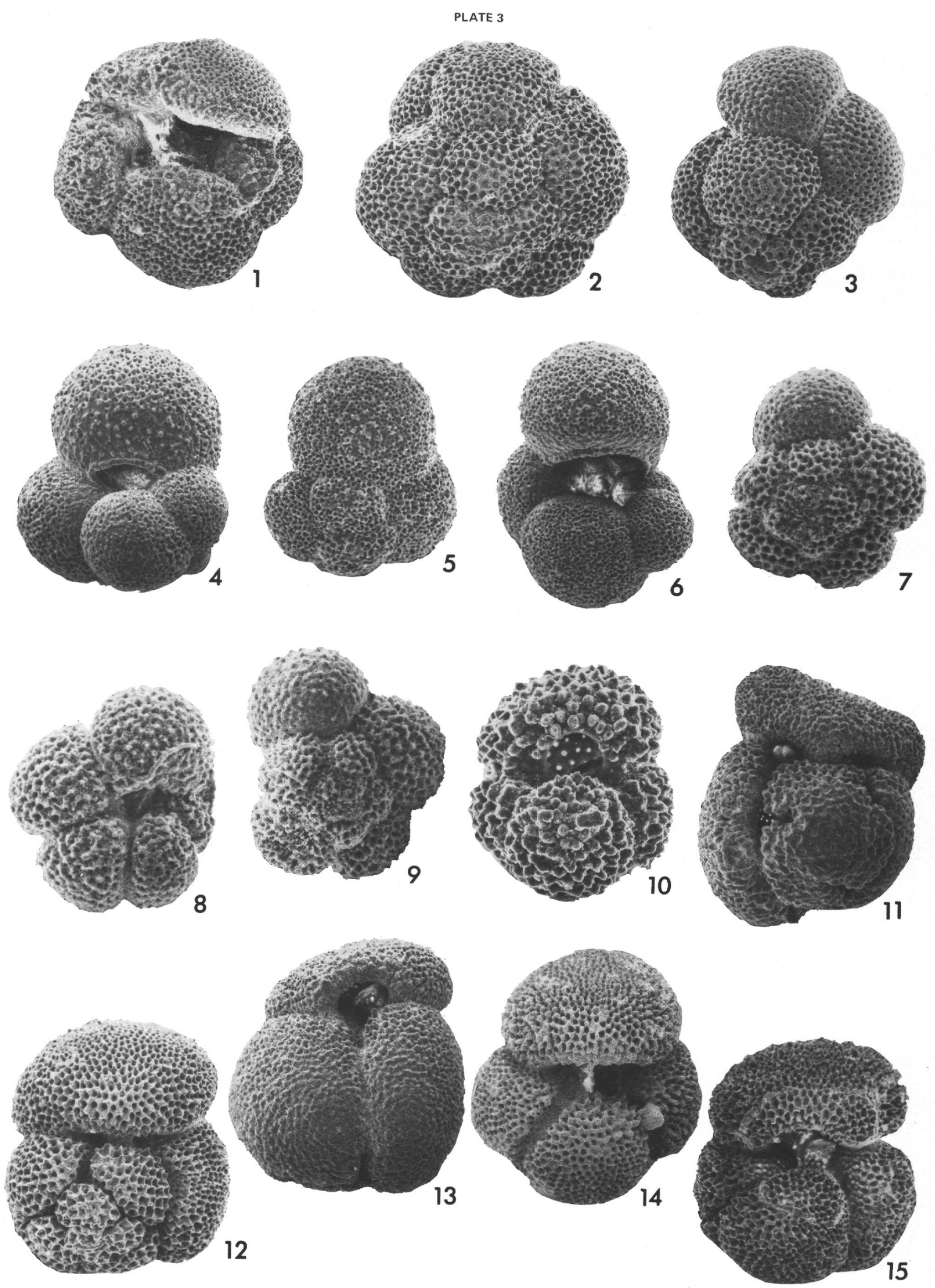


\section{PLATE 4}

Figure 1 Globigerinoides cf. mitra Todd. 21-208-14-1, 50-52 $\mathrm{cm}$; Spiral view; $\times 67$.

Figures 2-5 Globigerinoides obliquus Bolli.

2. 21-206-13, CC; Umbilical view; $\times 147$.

3. 21-206-14, CC; Umbilical view; $X 140$.

4. 21-206-18, CC; Spiral view; $X 107$.

5. 21-206-14, CC; Spiral view; $X 134$.

Figures 6, 7 Globigerinoides ruber (d'Orbigny) umbilical views.
6. 21-206-11, CC; $\times 122$.

7. $21-206-14, \mathrm{CC} ; \times 128$.

Figure $8 \quad$ Globigerinoides sp.

21-206-11, CC; Spiral view; X129.

Figure 9 Globigerinoides sp.

21-206-14, CC; Umbilical view; X111.

Figure $10 \quad$ Globigerinoides ruber pyramidalis (vanden Broeck). 21-206-13, CC; Side view; X116.

Figure 11, 12 Globigerinoides cf. quadrilobatus trilobus (Reuss).

11. 21-207A-9-5, 75-77 cm; Umbilical view; $\times 86$.

12. $21-207 \mathrm{~A}-10-1,110-112 \mathrm{~cm}$; Spiral view; $X 134$.

Figures 13-16 Globigerinoides transitoria Blow.

13. Spiral view; $\times 96$.

14. Umbilical view; $\times 118$.

15. Umbilical view; $\times 85$.

16. 21-207A-9-4, 75-77 cm; Umbilical view; $\times 105$. 


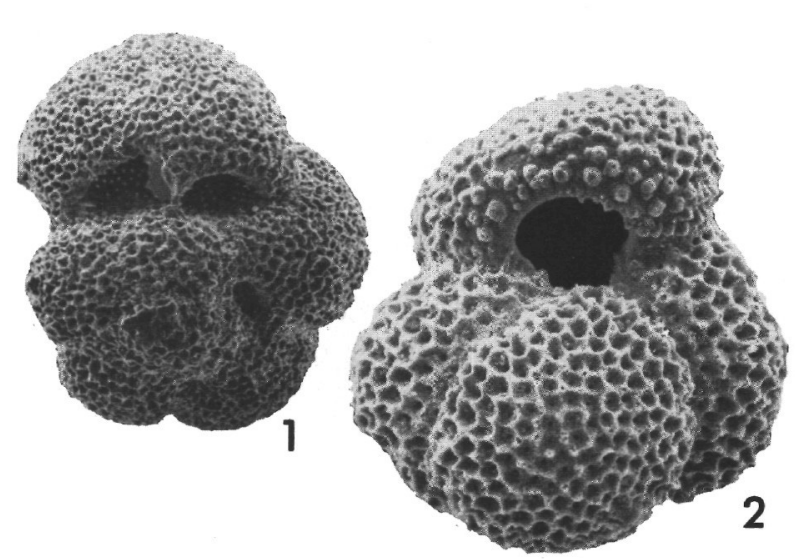

PLATE 4
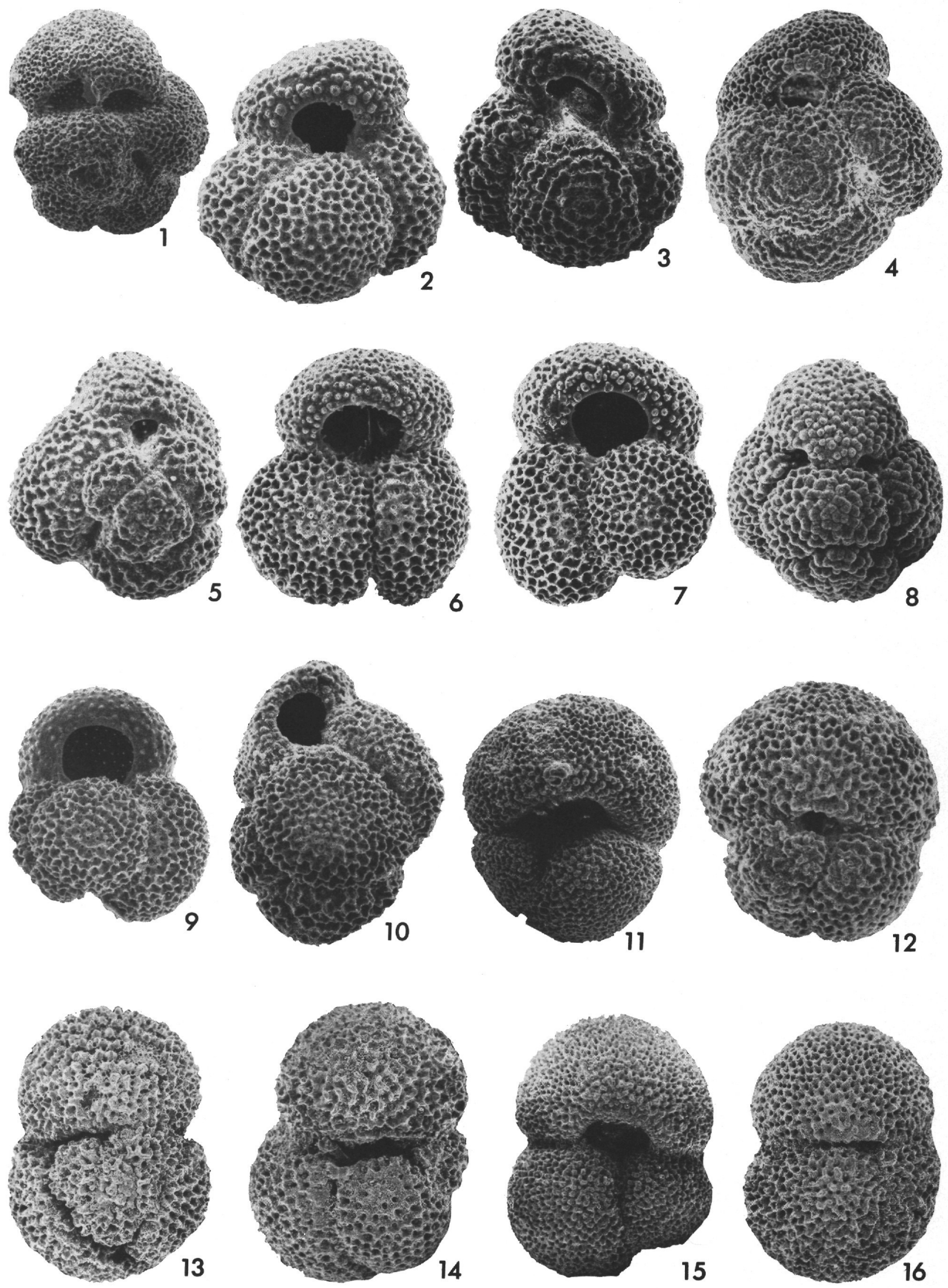


\section{PLATE 5}

Figures 1-5 Globigerinoides quadrilobatus trilobus (Reuss).

1. Spiral view, $X 137$.

2. Umbilical view; $\times 148$.

3. Umbilical view; $\times 144$

4. 21-207A-9-4, 75-77 cm; Umbilical view; $\times 125$.

5. 21-206-11, cc; Umbilical view; $\times 136$.

Figures 6, 7 Globigerinoides quadrilobatus quadrilobatus (d'Orbigny)

6. Umbilical view; $\times 67$.

7. 21-208-1-1, $52-54 \mathrm{~cm} ;$ Spiral view; $\times 59$.

Figure $8 \quad$ Globigerinoides quadrilobatus sacculifer (Brady) 21-206-31, CC; Umbilical view; X108.

Figure $9 \quad$ Globigerinoides sp. 21-207A-9-5, 75-77 cm; Umbilical view; X78.

Figures 10-13 Globigerinoides quadrilobatus sacculifer (Brady).

10. 21-206-18, CC; Umbilical view; X85.

11. 21-206-18, CC; Spiral view; $X 52$.

12. 21-206-13, CC; Umbilical view; $X 83$.

13. 21-206-13, CC; Spiral view; $X 83$.

Figures 14, 15 Globigerinoides fistulosus (Schubert) spiral views.

14. 21-208-2, CC; $\times 39$.

15. 21-208-30, CC; $\times 39$. 
PLATE 5
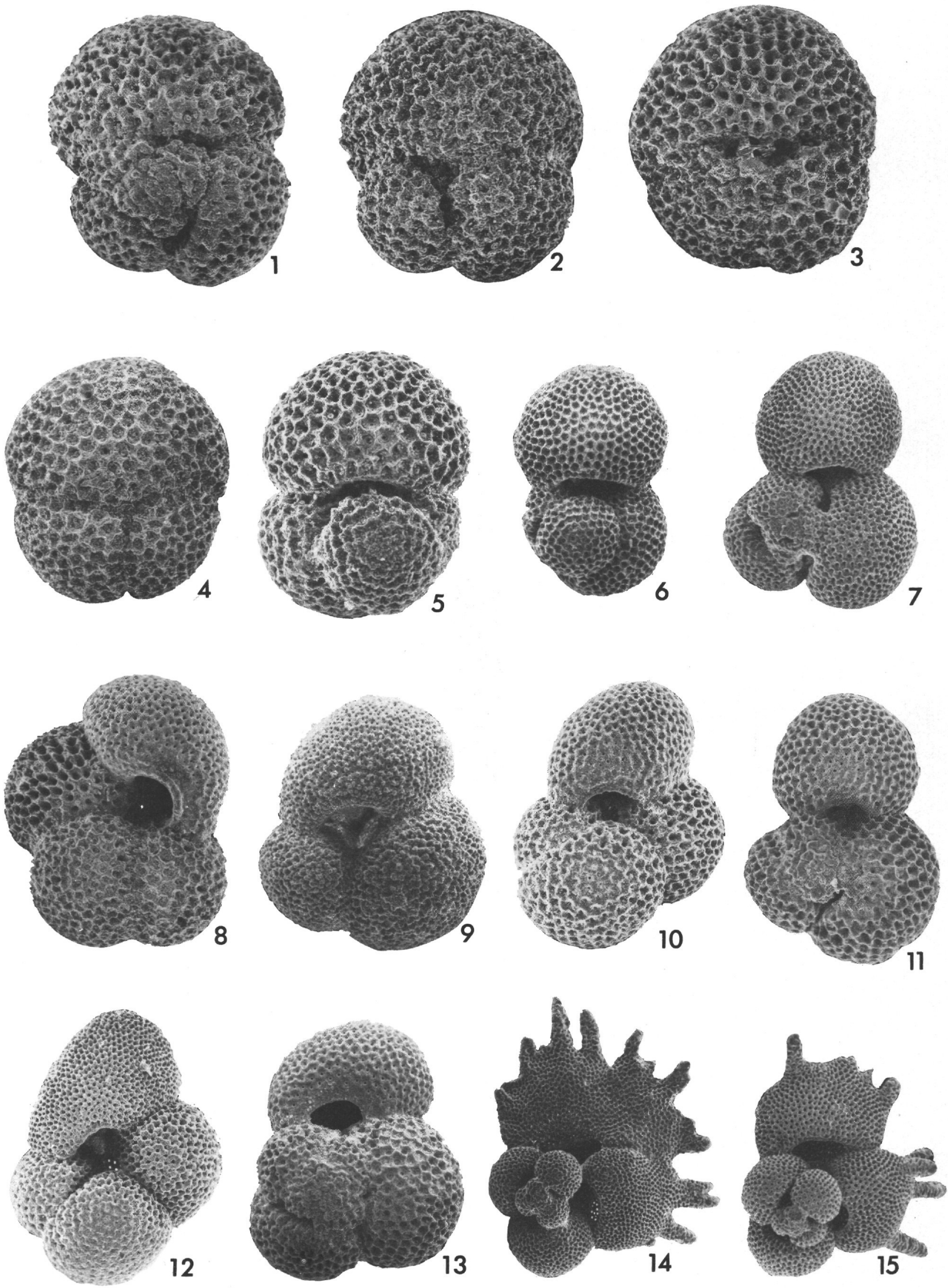


\section{PLATE 6}

Figure 1 Globigerinoides quadrilobatus sacculifer (Brady). 21-209-1, CC; Umbilical view.

Figures 2-11 Globigerinoides quadrilobatus fistulosus (Schubert). Simpler forms at end of evolutionary bioseries. Changes within range of bioseries shown on Plates 6 to 8 . Younger samples at top of plate.

2. 21-209-2-4, 146-148 cm; Umbilical view; X49.

3. Umbilical view; $\times 60$.

4. Umbilical view; $\times 62$.

5. 21-209-3-1, 98-100 cm; Spiral view; $\times 70$.

6. Spiral view; $\times 68$.

7. Umbilical view; $\times 49$.

8. 21-209-3-3, $148 \mathrm{~cm}$; Spiral view; $X 82$.

9. Umbilical view; $\times 71$.

10. Umbilical view; $\times 54$.

11. 21-209-3-4, 146-148 cm; Umbilical view; $\times 75$. 
PLATE 6
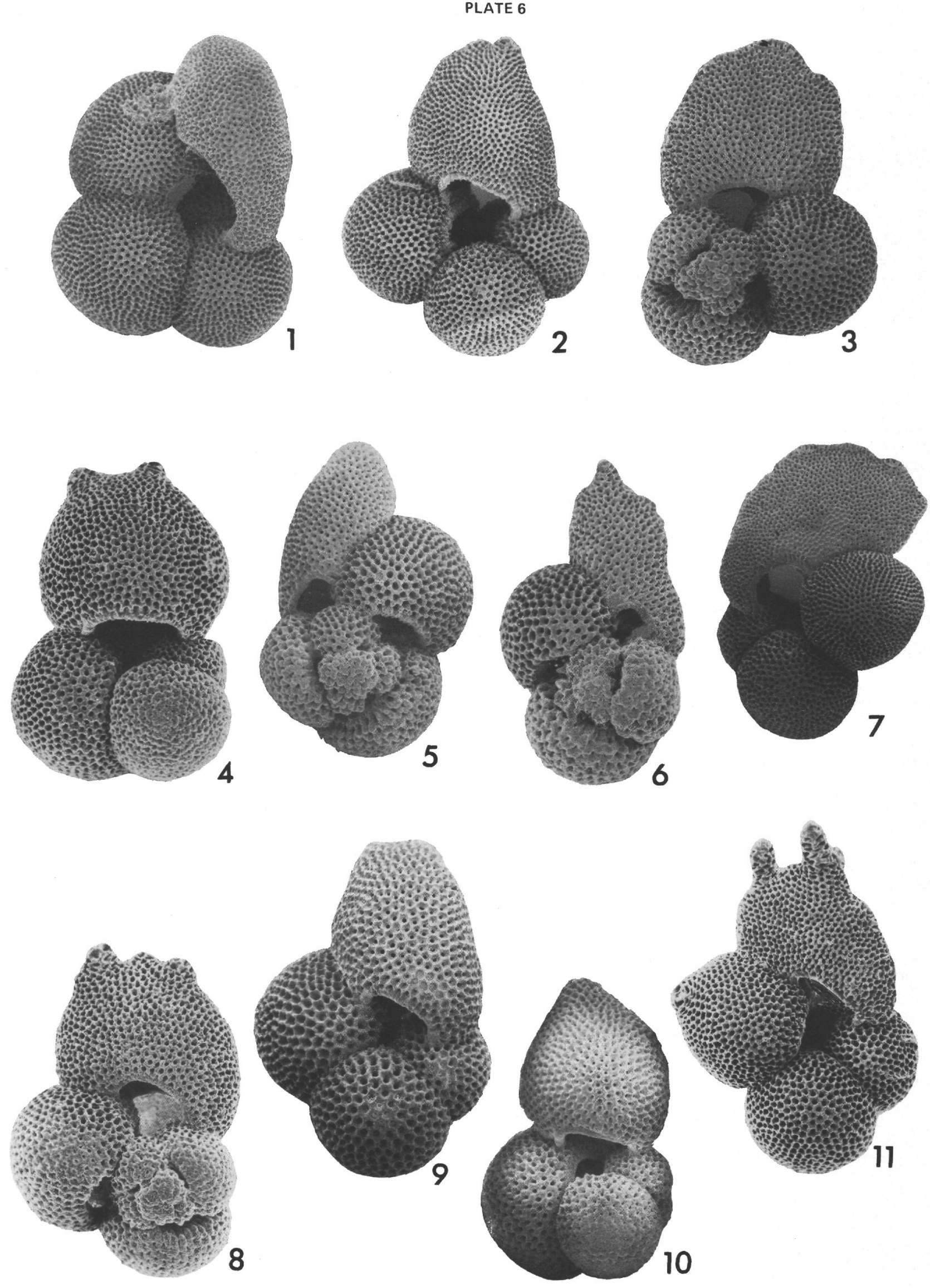


\section{PLATE 7}

Figures 1-13 Globigerinoides quadrilobatus fistulosus (Schubert). More complex forms in middle part of evolutionary bioseries. Younger samples at top of plate.

1. 21-209-3-5, 146-148 cm; Umbilical view; X67.

2. Spiral view; $\times 54$.

3. Spiral view; $\times 40$.

4. Spiral view; $\times 36$.

5. 21-209-3, CC; Spiral view; X43.

6. Spiral view; $\times 58$.

7. Spiral view; $\times 48$.

8. Spiral view; $\times 42$.

9. 21:209-4-5, $72-74 \mathrm{~cm}$; Spiral view; $X 54$.

10. Spiral view; $\times 43$.

11. Umbilical view; $\times 39$.

12. Spiral view; $\times 61$.

13. 21-209-4, CC; Umbilical view; $\times 50$. 

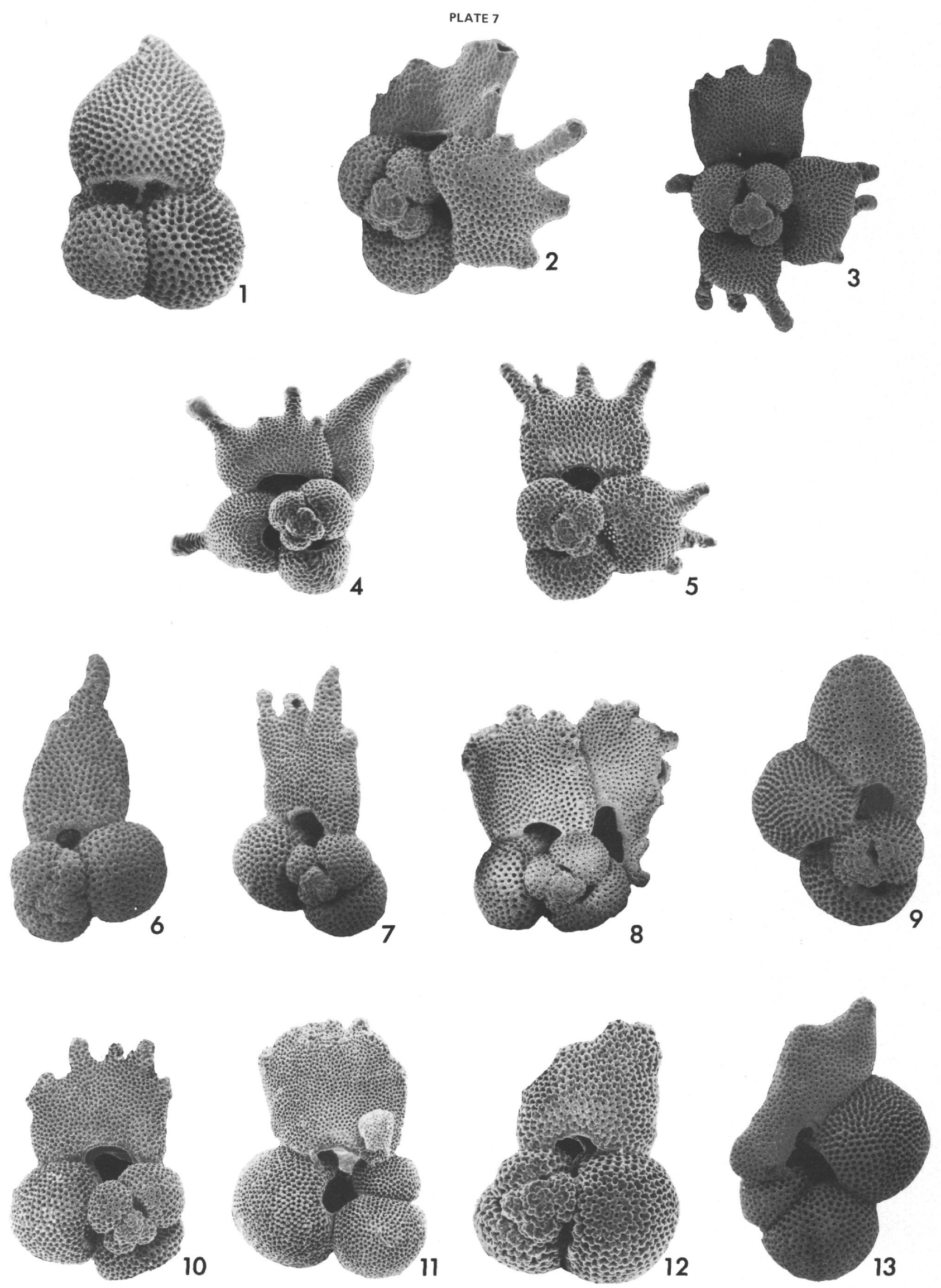


\section{PLATE 8} $\begin{array}{ll}\text { Figures 1-10 } & \begin{array}{l}\text { Globigerinoides quadrilobatus fistulosus (Schubert) } \\ \text { Simpler forms at beginning of evolutionary bioseries. }\end{array}\end{array}$ Younger samples at top of plate.
1. Umbilical view; $\times 69$.
2. Spiral view; $\times 58$.
3. Spiral view; $\times 57$.
4. Spiral view; $\times 52$.
5. 21-209-5-1,73-75 cm; Umbilical view; $\times 49$.
6. Umbilical view; $\times 63$.
7. Umbilical view; $\times 73$.
8. Spiral view; $\times 47$.
9. Spiral view; $X 68$.
10. 21-209-5-2, 146-148 cm; Umbilical view; $\times 56$.

Figures 11-14 Globigerinoides quadrilobatus sacculifer (Brady)

Forms immeidately preceding evolutionary bioseries of G. quadrilobatus fistulosus.

11. Spiral view; $X 61$.

12. Spiral view; $\times 82$.

13. Umbilical view; $\times 59$.

14. $21-209-5-4,72-74 \mathrm{~cm}$; Spiral view; $\times 72$. 
PLATE 8
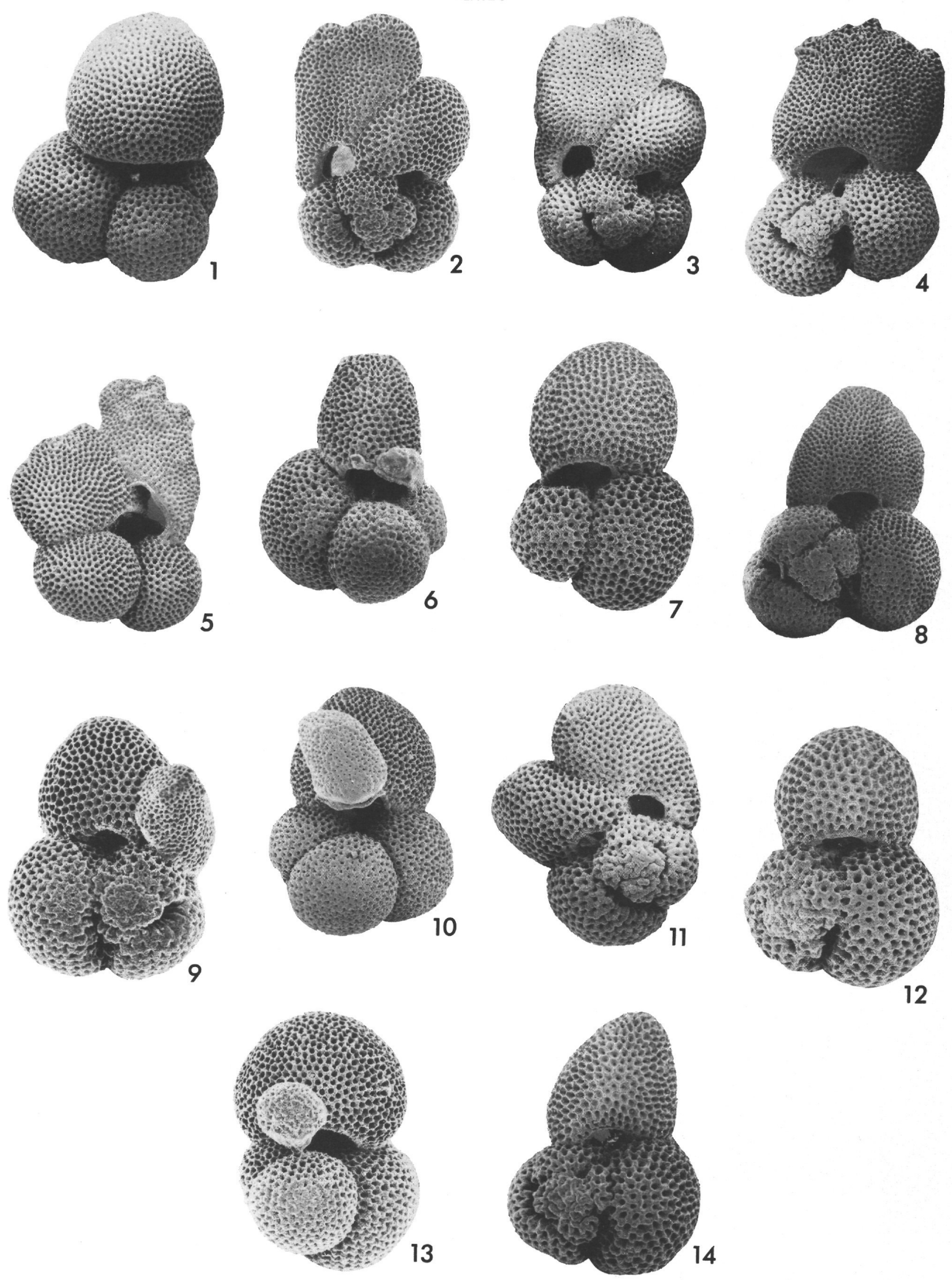


\section{PLATE 9}

Figures 1-5 Hastigerina aequilateralis (Brady).

1. Spiral view; $\times 79$.

2. Umbilical view; $\times 71$.

3. Side view; $\times 76$.

4. 21-206-13, CC; Side view; $\times 76$.

5. 21-206-25, CC; Umbilical view; $\times 148$.

Figures 6,7 Hastigerina pelagica (d'Orbigny).

6. Apertural view; $\times 63$.

7. 21-203-1-1, 70-72 cm; Side view; $\times 67$.

Figure $8 \quad$ Catapsydrax dissimilis (Cushman and Bermudez).

$$
21-20641, \mathrm{cc} ; \times 88 \text {. }
$$

Figures 9-13 Globoquadrina dehiscens (Chapman, Parr, and Collins)

9. Spiral view; $\times 68$.

10. Umbilical view; $\times 61$.

11. Side view; $21-208-17-1,50-52 \mathrm{~cm}$; Side view; $\times 79$.

12. 21-206-32, cc; Umbilical biew; $\times 105$.

13. 21-206-24, cc; Spiral view; $\times 108$.

Figures 14, 15 Globoquadrina venezuelana (Hedberg).

14. 21-206-25, CC; Spiral view; $\times 67$.

15. 21-206-23, CC; Umbilical view; $\times 69$. 
PLATE 9
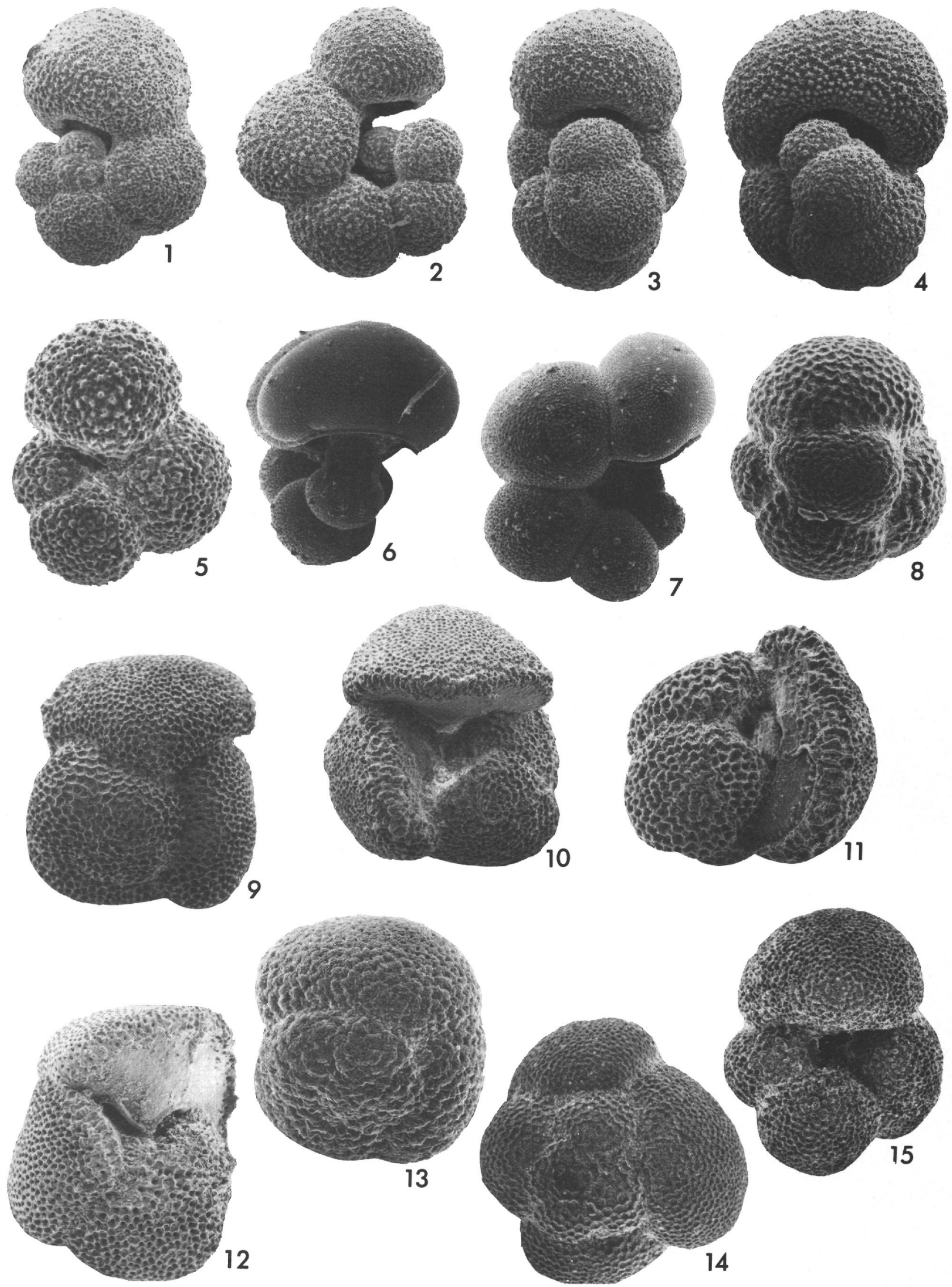


\section{PLATE 10}

Figures 1-4 Globoquadrina cf. altispira (Cushman and Jarvis)

1. Umbilical view; $\times 118$.

2. Spiral view; $X 136$.

3. Umbilical view; $\times 109$.

4. 21-206-31, CC; Spiral view; $\times 138$.

Figures 5-7 Globorotalia dutertrei (d'Orbigny).

5. 1-208-1-1, 52-54 cm; Umbilical view; X69..

6. Spiral view; $\times 79$.

7. 21-206-11-3, 30-32 cm; Side view; $\times 97$.

Figures 8,9 Globorotalia humeros $a$ Takayanagi and Saito.

8. Umbilical view; $\dot{X} 114$.

9. 21-206-13, CC; Side view; $\times 101$.

Figures 10-13 Globorotalia acostaensis Blow.

10. Umbilical view, $X 100$.

11. Side view; $\times 95$.

12. Umbilical view; $\times 100$.

13. $21-208-13-1,50-52 \mathrm{~cm}$; Spiral view; $\times 101$. 


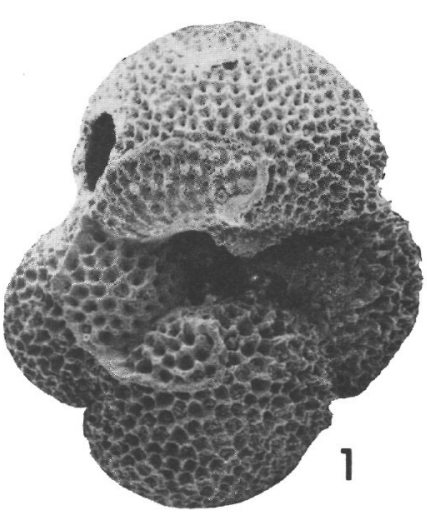

PLATE 10
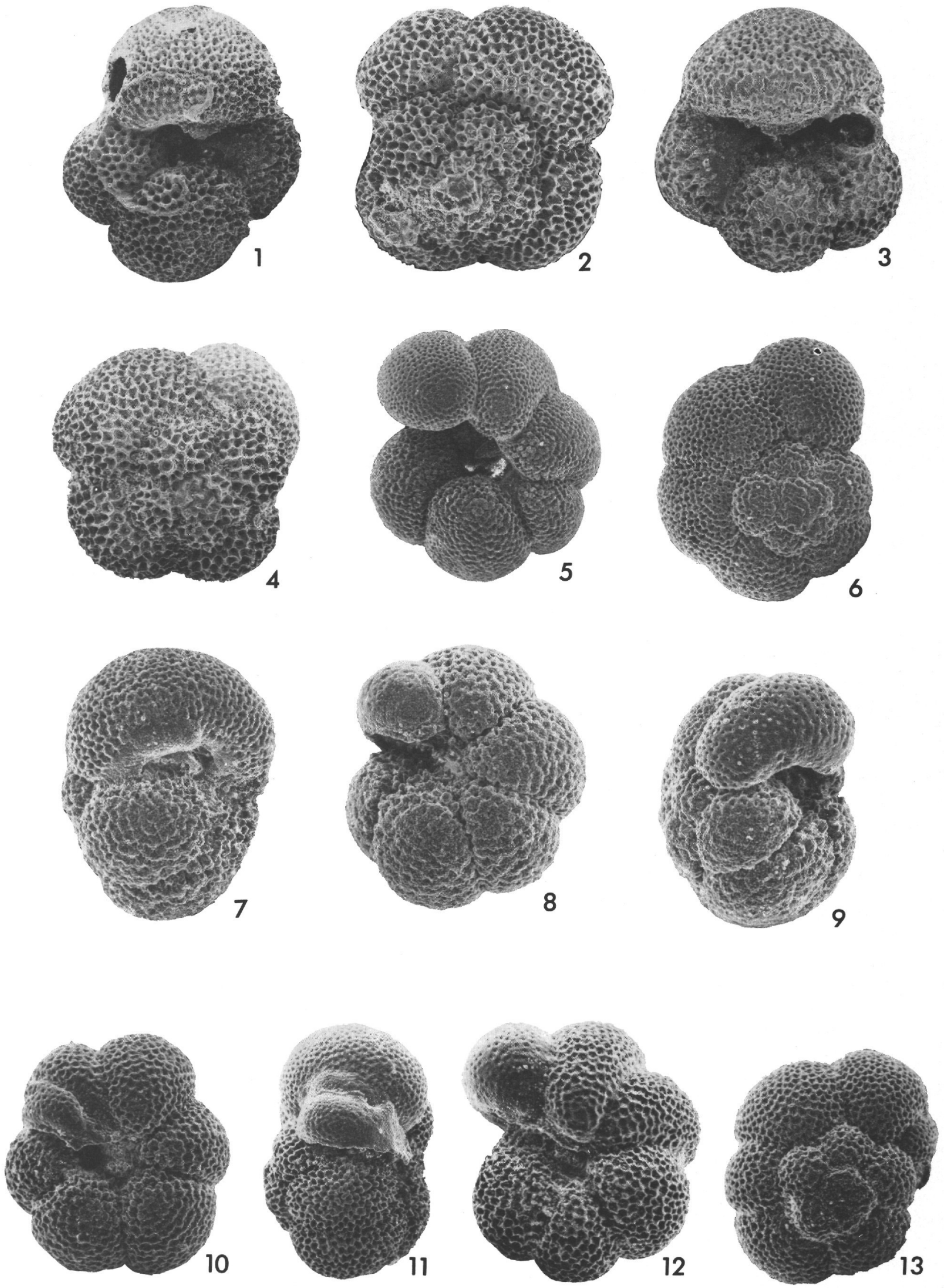


\section{PLATE 11}

Figures 1-3, 5 Globoquadrina altispira (Cushman and Jarvis).

1. Umbilical view; $\times 95$.

2. Spiral view; $\times 93$.

3. Umbilical view; $\times 92$;

5. 21-207A-9-3, 75-77 cm; Side view; $X 66$.

Figure 4 Globoquadrina cf. altispira (Cushman and Jarvis). 21-208-8 CC; Side view; X98.

Figures 6-9 Globorotalia panda Jenkins.

6. 21-206-27, CC; Spiral view; $\times 87$.

7. 21-206-27-2, 90-92 cm; Side view; $X 101$.

8. 21-207A-10-2, 75-77 cm; Umbilical view; $\times 107$.

9. 21-206-31, CC; Umbilical view; $\times 91$.

Figures 10-12 Globorotalia margaritae Bolli and Bermudez.

10. Spiral view; $\times 132$.

11. Umbilical view; $X 113$.

12. $21-208-8, \mathrm{CC} ;$ Side view; $\times 115$.

Figures 13, 14 Globorotalia cibaoensis Bermudez.

13. Umbilical view; $X 89$.

14. 21-208-8, CC; Spiral view; $X 88$.

Figures 15, 16 Globorotalia scitula (Brady).

15. Umbilical view; $X 82$.

16. 21-206-6, CC; Spiral view; $\times 67$. 
PLATE 11
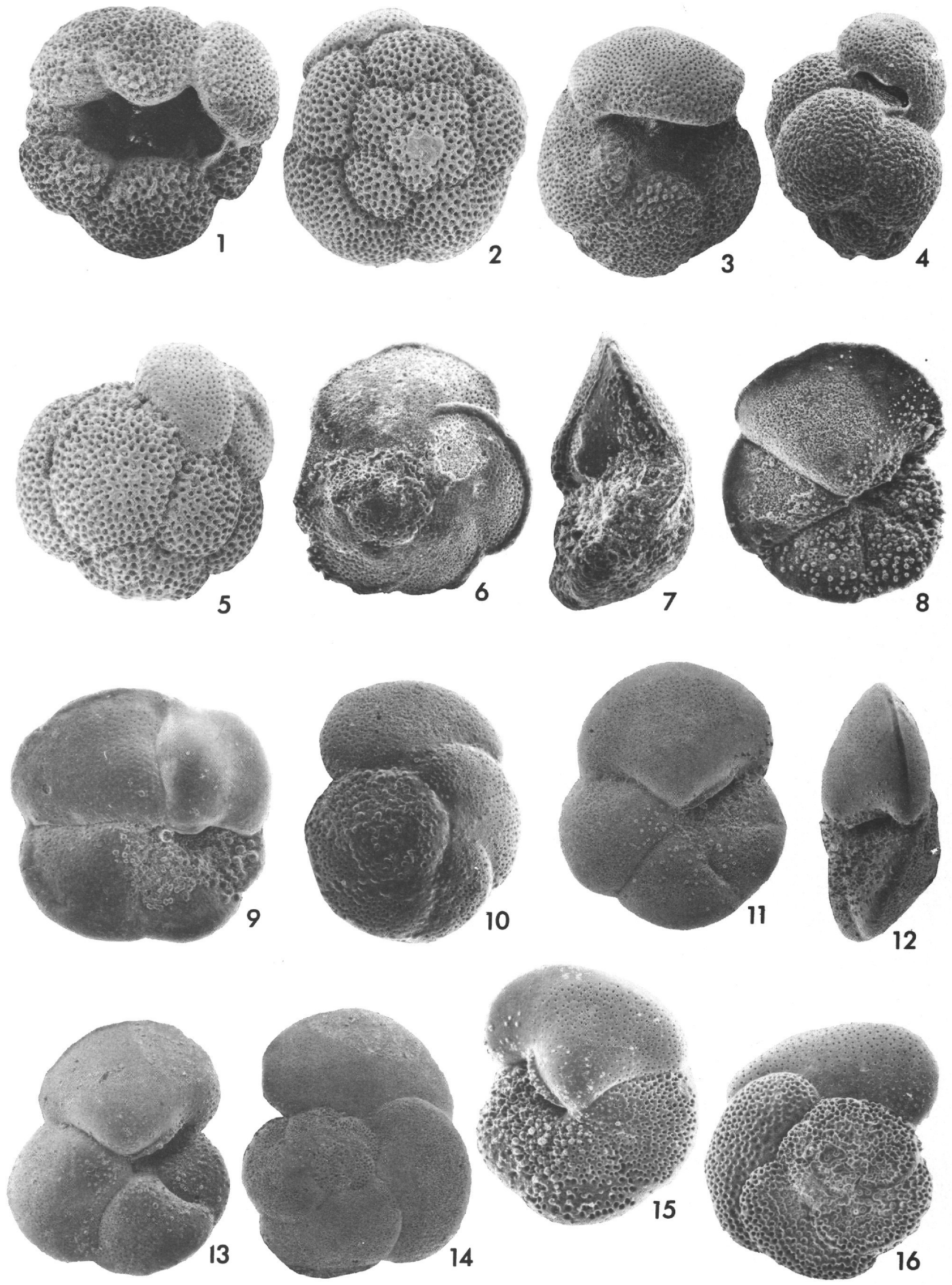


\section{PLATE 12}

Figures 1-4 Globorotalia cf. menardii (Parker, Jones, and Brady).

1. 21-206-13, CC; Spiral view; $X 61$.

2. 21-206-13, CC; Umbilical view; $X 73$.

3. 21-206-14, CC; Umbilical view; $\times 94$.

4. 21-206-13, CC; Side view; X79.

Figures 5-9 Globorotalia menardii (Parker, Jones, and Brady).

5. 21-206-7, CC; Spiral view; $X 40$.

6. 21-209-1, CC; Umbilical view; $\times 48$.

7. 21-206-18, CC; Spiral view; $X 66$.

8. 21-209-1, CC; Side view; X43.

9. 21-206-8, CC; Side view; $\times 64$.

Figures 10, 11 Globorotalia tumida flexuosa (Koch).

10. Side view; $X 42$.

11. 21-206-1, CC; Umbilical view; $X 48$.

Figures 12-16 Globorotalia tumida (Brady).

12. 21-206-8, CC; Spiral view; $\times 47$.

13. 21-206-14, CC; Side view; $X 45$.

14. 21-206-3-3, 148-50 cm; Umbilical view; $X 41$.

15. 21-206-8, CC; Umbilical view; $\times 42$.

16. 21-206-6, CC; Umbilical view; $X 43$. 
PLATE 12
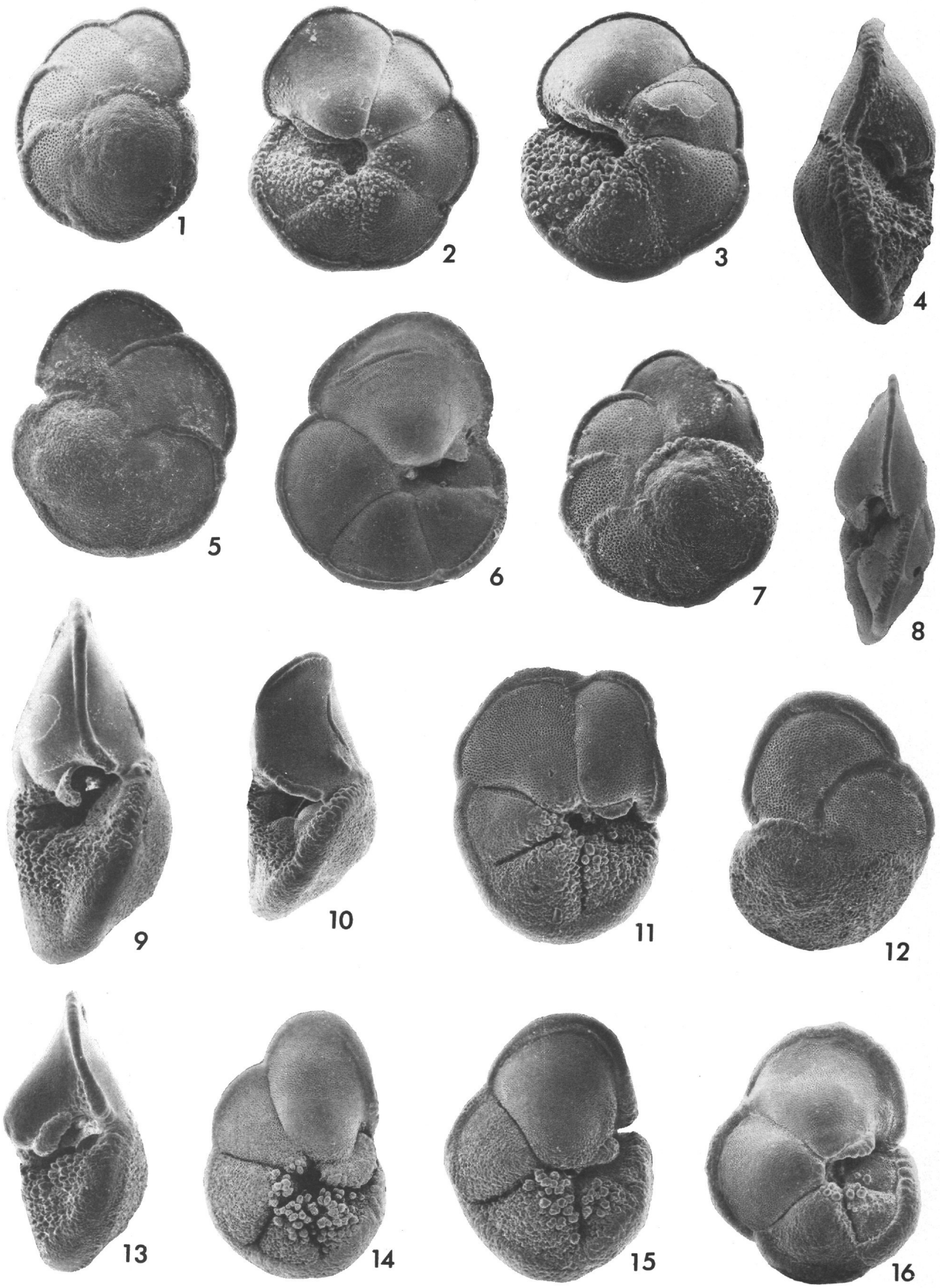


\section{PLATE 13}

Figures 1,2 Globorotalia multicamerata Cushman and Jarvis.

1. Umbilical view; $\times 51$.

2. 21-206-3-3, 148-150 cm; Spiral view; $X 49$.

Figures 3-5 Globorotalia praemenardii Cushman and Stainforth.

3. 21-206-27, CC; Side view; X132.

4. 21-206-27, CC; Umbilical view; $X 89$.

5. 21-206-28, CC; Umbilical view; X104.

Figures 6-8 Globorotalia peripheroronda Blow and Banner.

6. 21-207A-10-1, 110-112 cm; Spiral view; X143.

7. 21-207A-10-2, 75-77 cm; Umbilical view; $X 128$.

8. 21-206-31, CC; Side view; $\times 141$.

Figures 9-11 Globorotalia perpheroacuta Blow and Banner.

9. 21-206-32, CC; Umbilical view; $\times 92$.

10. 21-208-20, CC; Side view; $X 111$.

11. 21-206-28, CC; Spiral view; $X 113$.

Figures 12-16 Globorotalia mayeri Cushman and Ellisor.

12. 21-207A-10-1, 110-112 cm; Umbilical view; X143.

13. 21-206-28, CC; Spiral view; $X 123$.

14. 21-207A-10-1, 110-112 cm; Spiral view; $\times 79$.

15. 21-206-28, CC; Side view; $X 121$.

16. 21-206-28, CC; Umbilical view; $X 128$. 

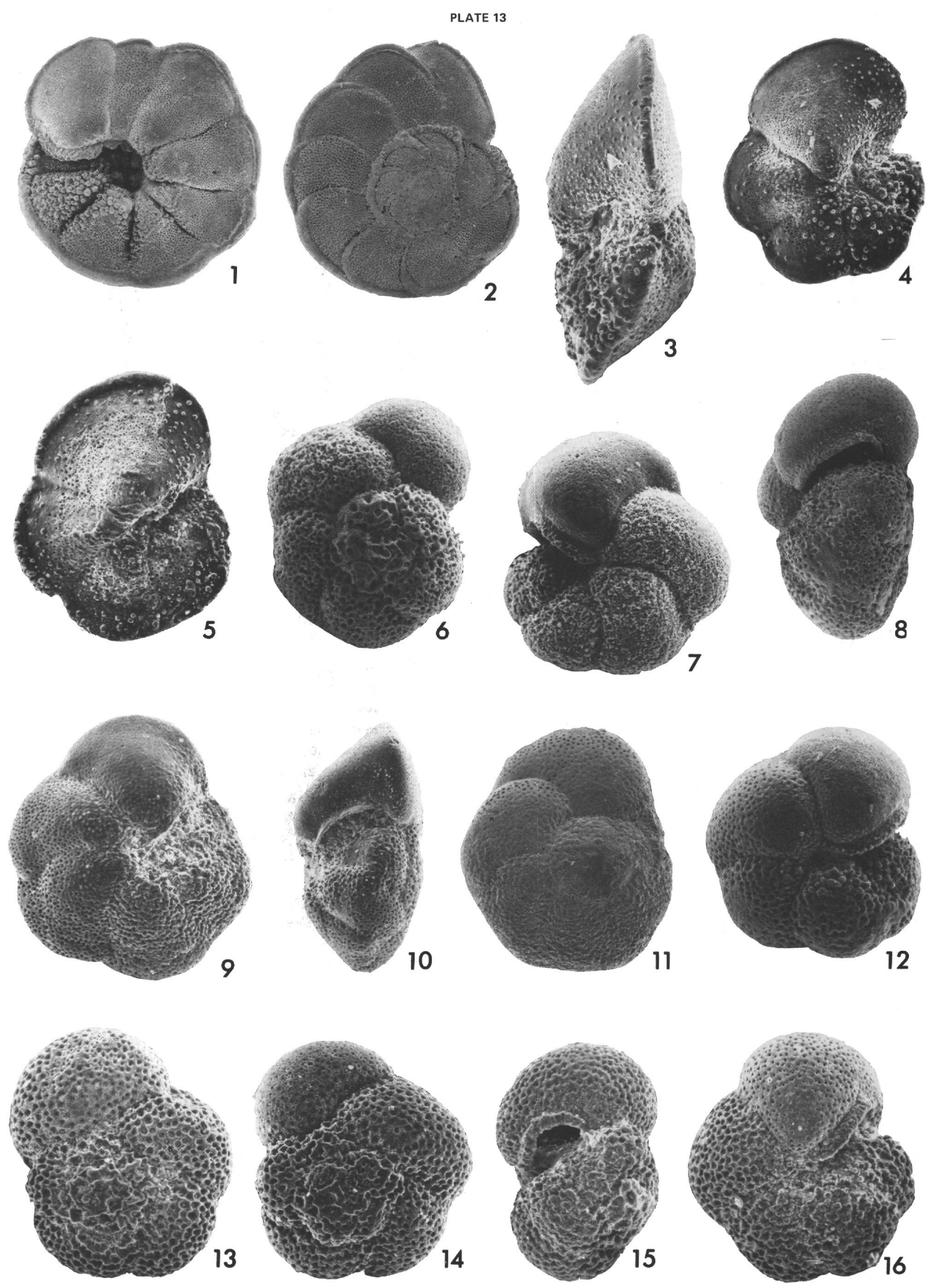
PLATE 14

Figures 1, 2 Globorotalia siakensis (LeRoy).

1. Umbilical view; $\times 115$.

2. 21-206-31, CC; Spiral view; $\times 133$.

Figures 3-6 Globorotalia continuosa Blow.

3. Side view; $\times 205$.

4. Umbilical view; $\times 220$.

5. 21-206-24, CC; Spiral view; $\times 206$.

6. 21-206-26, CC; Umbilical view; X170.

Figures 7-14 Globorotalia crassaformis Galloway and Wissler.

7. 21-206-18, CC; Umbilical view; $X 86$.

8. 21-206-18, CC; Umbilical view; $X 72$.

9. 21-206-11-3, 30-32 cm; Spiral view; $\times 97$.

10. 21-206-14, CC; Umbilical view; $X 79$.

11. 21-206-18, CC; Spiral view; $X 95$.

12. 21-206-18, CC; Side view; $X 93$.

13. 21-206-12-3, 30-32 cm; Close-up of edge showing keel; $\times 322$.

14. 21-206-13, CC;Close-up of edge showing rounded porous periphery; $\times 269$. 
PLATE 14
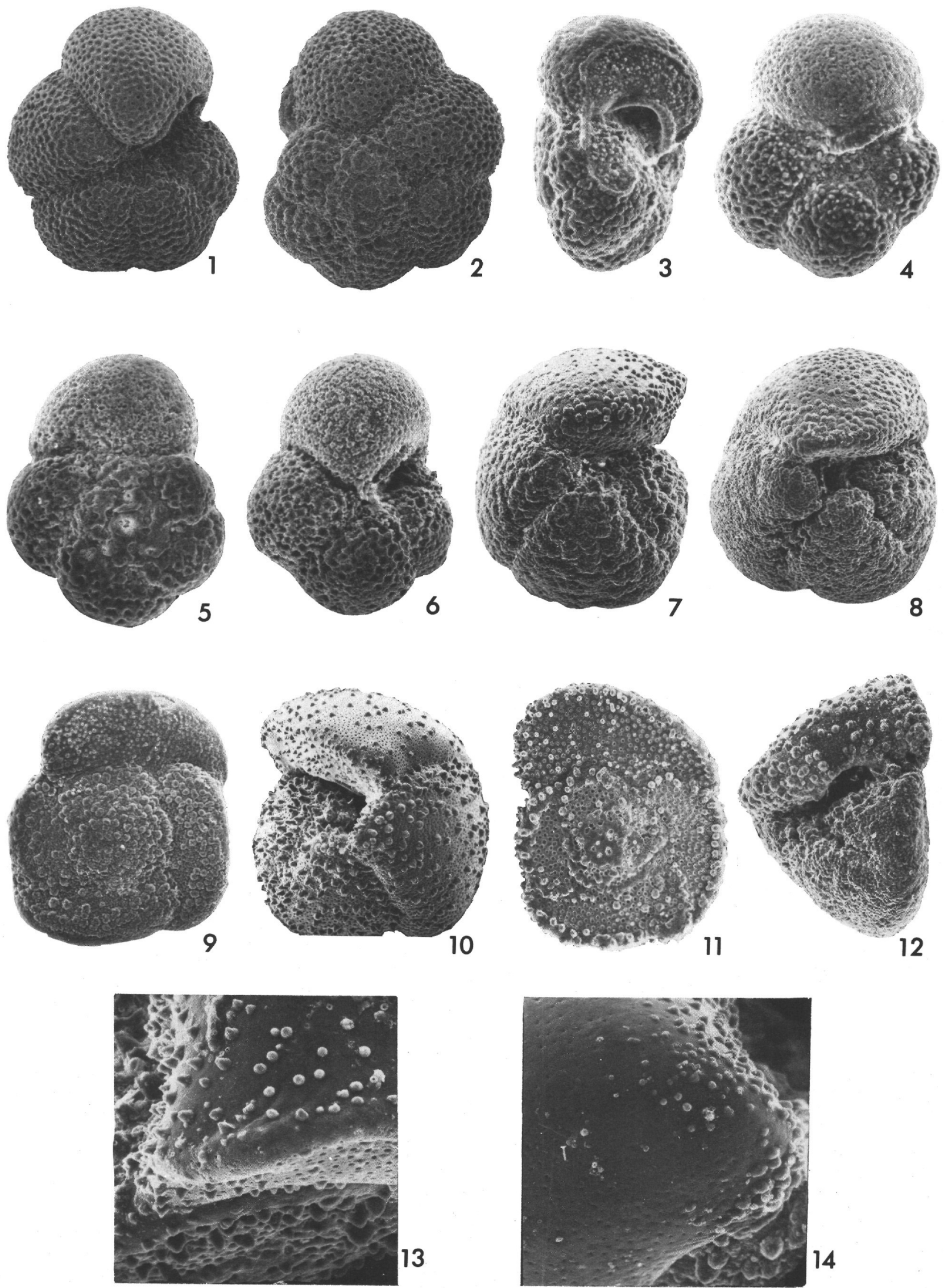


\section{PLATE 15}

Figures 1-4 Globorotalia crassaformis Galloway and Wissler X G. tosaensis Takayanagi and Saito. Form transitional between these two species at beginning of evolution of $G$. tosaensis.

1. Side view, $\times 100$.

2. Umbilical view; $\times 92$.

3. Spiral view, $\times 79$.

4. 21-206-13, CC; Edge view; $\times 267$.

Figures 5-14 Globorotalia tosaensis Takayanagi and Saito.

5. Umbilical view; $\times 94$.

6. 21-206-12-3, 30-32 cm; Spiral view; $\times 79$.

7. Spiral view; $\times 86$.

8. Side view; $\times 89$.

9. Umbilical view; $\times 117$.

10. Edge view; $\times 272$.

11. Edge view; $\times 275$.

12. 21-206-13, CC; Edge view; $\times 278$.

13. Edge view; $\times 278$.

14. $21-206-12-3,30-32 \mathrm{~cm}$; Edge view; $X 328$. These close-up views of the peripheral edge show the gradation that occurs between porous nonkeeled to nonporous keeled margins. 
PLATE 15
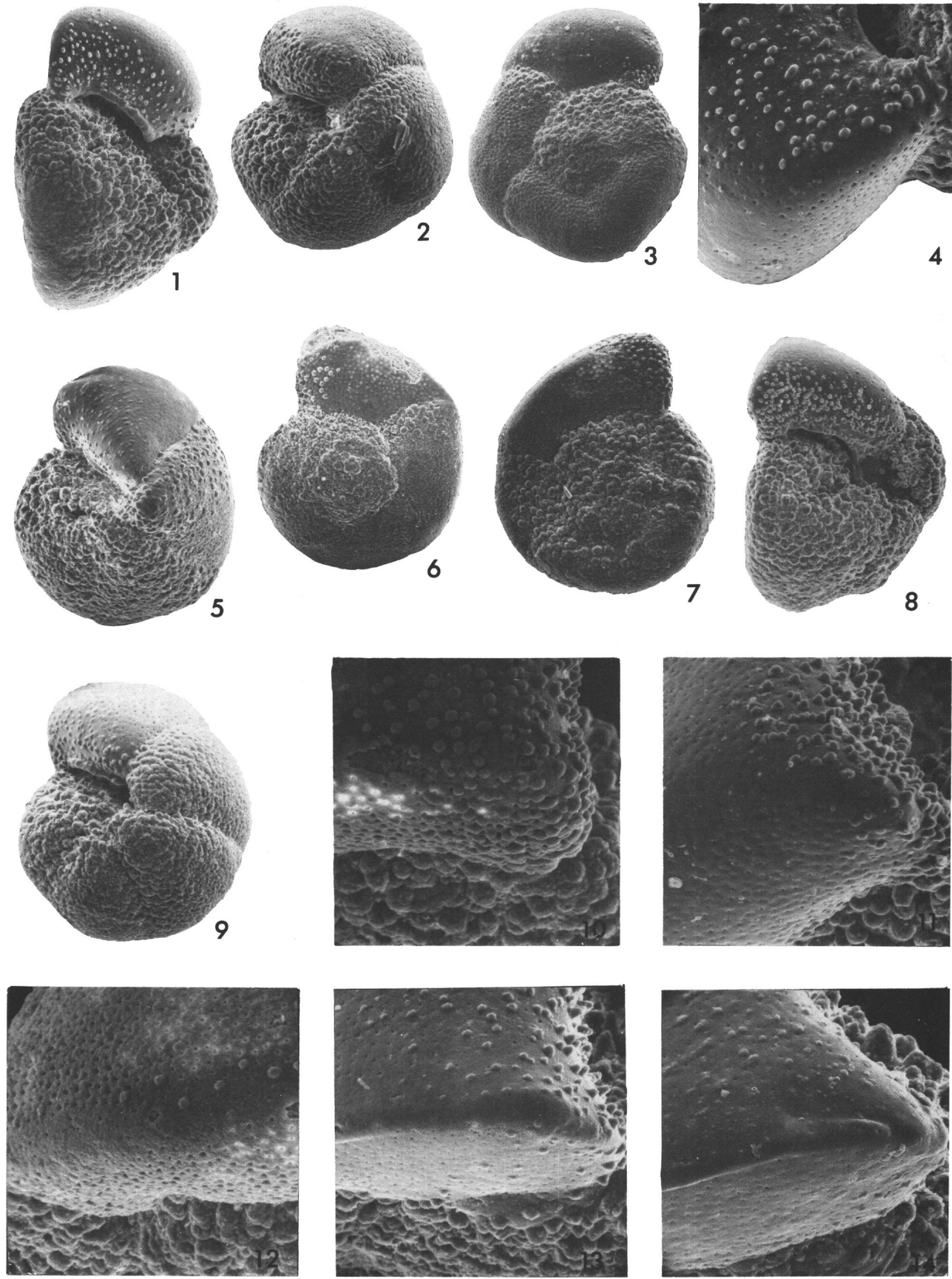
PLATE 16

Figures 1-3 Globorotalia truncatulinoides (d'Orbigny).

1. Umbilical view; $\times 71$.

2. Side view; $\times 79$.

3. 21-206-6, CC; Spiral view; $X 80$;

Figures 4-11 Globorotalia miozea conoidea Walters.

4. 21-206-31, CC; Spiral view; $\times 109$.

5. Umbilical view; $\times 77$.

6. Spiral view; $\times 72$.

7. Umbilical view; $\times 75$.

8. 21-207A-5-3, 75-77 cm; Umbilical view; $\times 57$.

Early part of evolutionary bioseries to Globorotalia conomiozea Kennett.

9. Side view; $\times 70$.

10. Spiral view; $X 63$.

11. 21-206-21, CC; Umbilical view; $X 69$. 


$$
\begin{aligned}
& 610 \\
& 000 \\
& 0180
\end{aligned}
$$


PLATE 17

Figures 1-3 Globorotalia miozea conoidea Walters.

1. Spiral view; $\times 100$.

2. Umbilical view; $\times 93$.

3. 21-207A-5-3, 75-75 cm; Side view; $\times 80$.

Early part of evolutionary bioseries to Globorotalia conomiozea Kennett.

Figures 4-13 Globorotalia conomiozea Kennett. Specimens from within evolutionary bioseries. Younger sample in bottom half of plate.

4. Side view; $\times 74$.

5. Spiral view; $\times 83$.

6. Side view; $\times 88$.

7. 21-207A-5-3, 75-77 cm; Side view; $\times 74$.

8. Spiral view; $\times 99$.

9. Side view; $\times 83$.

10. Side view; $X 116$.

11. Umbilical view; $\times 78$.

12. Side view; $X 111$.

13. 21-207A-4, CC; Spiral view; $\times 134$. 
PLATE 17
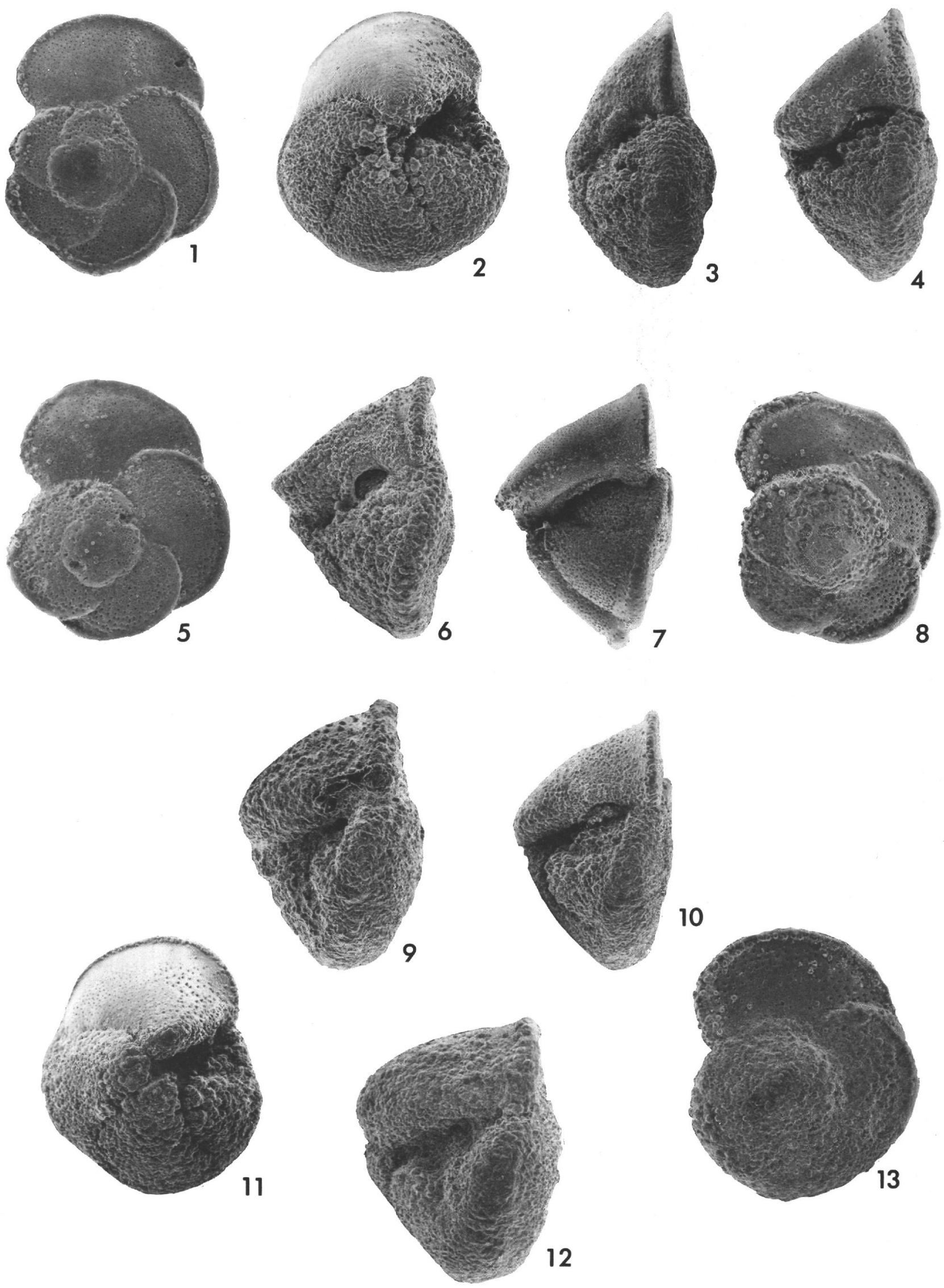
PLATE 18

Figure 1 Globorotalia conomiozea Kennett.

21-207A-4-1, 75-77 cm; Side view; X 113.

Intermediate form between $G$. conomiozea and $G$. puncticulata.

Figures 2-11 Globorotalia punticulata (d'Orbigny).

2-7. Early forms derived from G. conomiozea.

8-11. Advanced forms leading to Globorotalia inflata.

2. Umbilical view; $\times 115$.

3. Side view; $\times 127$.

4. Side view; $\times 132$.

5. Spiral view; $X 146$.

6. Side view; $X 114$.

7. $21-207 \mathrm{~A}-4-1,75-77 \mathrm{~cm}$; Umbilical view; $\times 134$.

8. Side view; $\times 103$.

9. 21-206-18, CC; Umbilical view; X98.

10. Spiral view; $\times 106$.

11. 21-206-14, CC; Side view; $X 150$.

Figures 12-16 Globorotalia inflata (d'Orbigny).

12. Spiral view; $\times 75$.

13. Umbilical view; $\times 79$.

14. 21-206-11, CC; Side view; $X 92$.

15. 21-206-13, CC; Umbilical view; $\times 144$.

16. 21-206-11, CC; Umbilical view; X92. 
PLATE 18
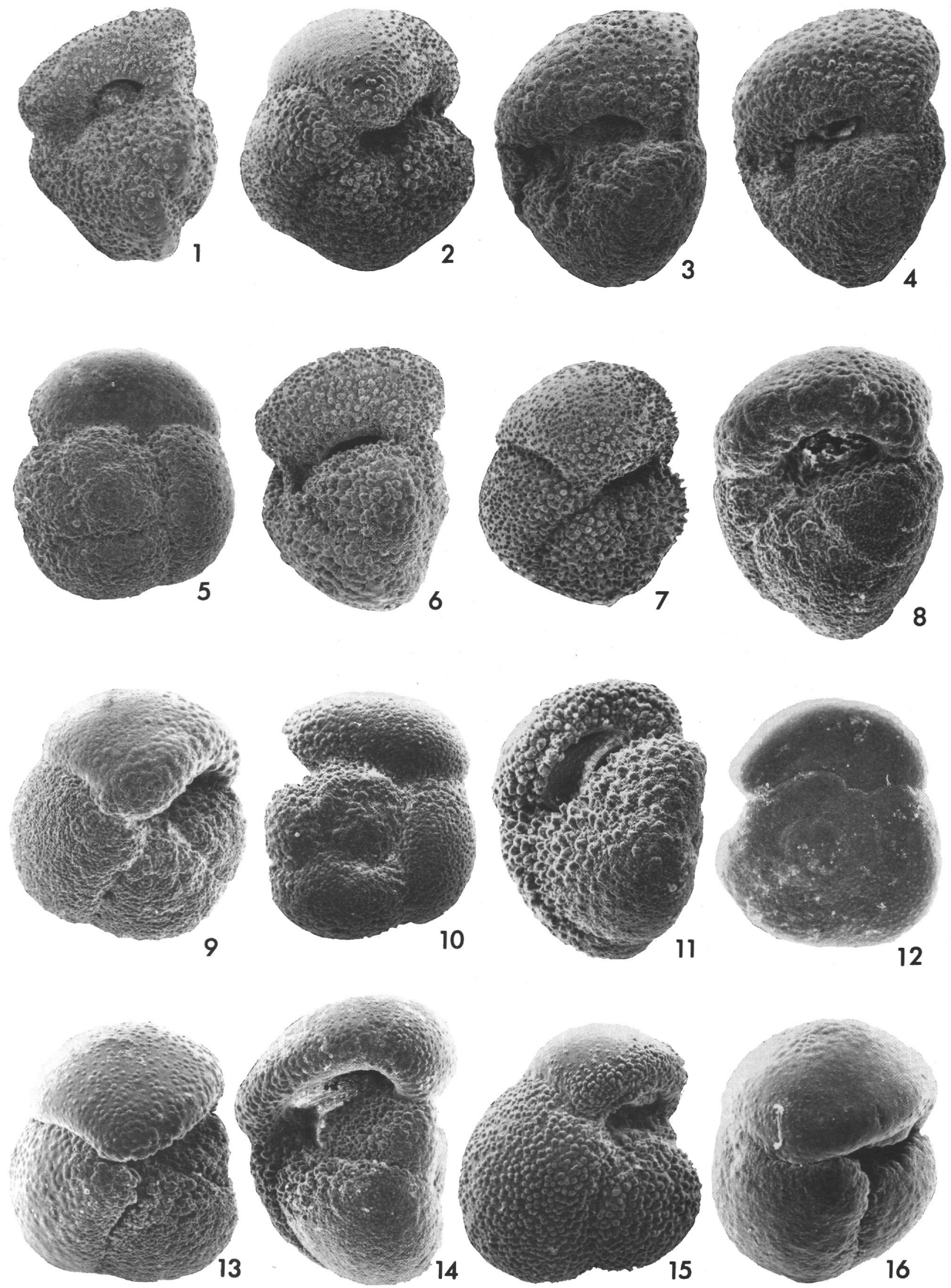


\section{PLATE 19}

Figures 1-3 Globorotalia pseudokugleri Blow.

1. Umbilical view; $\times 196$.

2. Side view; $\times 213$.

3. 21-206-41, CC; Spiral view; $\times 200$.

Figures 4-6 Globorotaloides hexagona (Natland).

4. Umbilical view; $\times 200$.

5. Umbilical view; $\times 159$.

6. 21-206-14, CC; Spiral view; $\times 167$.

Figure $7 \quad$ Globigerinoides sicanus De Stefani. 21-207A-9-4, 75-77 cm; Spiral view; X104.

Figures 8-11 Praeorbulina glomerosa circularis (Blow).
8. 21-207A-9-3, 75-77 cm; $\times 151$.
9. $\times 128$.
10. $\times 77$.
11. 21-207A-9-2, 75-77 cm; $\times 82$.

Figures 12, 13 Orbulina suturalis Bronnimann.

12. $\times 64$.

13. $21-208-13-5,50-52 \mathrm{~cm} ; \times 69$. 
PLATE 19
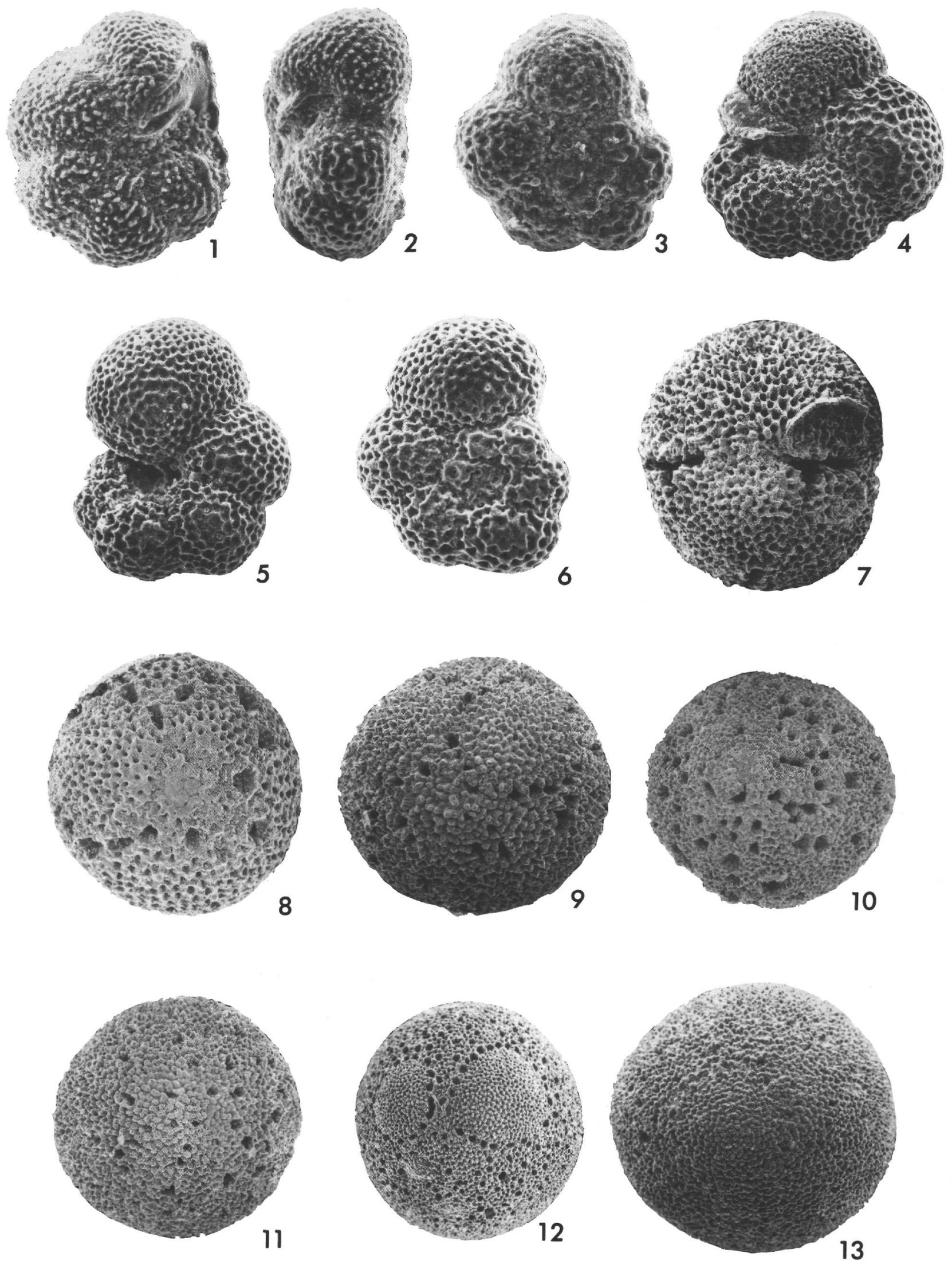


\section{PLATE 20}

Figures 1-6 Orbulina suturalis Bronnimann.
1. Internal view; $\times 72$.
2. Internal view; $\times 70$.
3. Spiral view of initial trochospiral stage; $\times 173$.
4. Internal view; $\times 61$.
5. Internal view; $\times 61$.
6. 21-208-13-5, 50-52 cm; Internal view; $\times 90$.

Figure 7 Orbulina universa d'Orbigny. 21-208-8, CC; X44.

Figures 8,9 Pulleniatina obliquiloculata (Parker and Jones).

8. Side view; $\times 66$.

9. 21-206-7, CC; Spiral view; $\times 75$.

Figures 10-12 Pulleniatina primalis Banner and Blow.

10. 21-206-17-5, 30-32 cm; Spiral view; $\times 93$.

11. 21-206-19, CC; Umbilical view; X106.

12. 21-206-21, CC; Spiral view; $X 117$. 

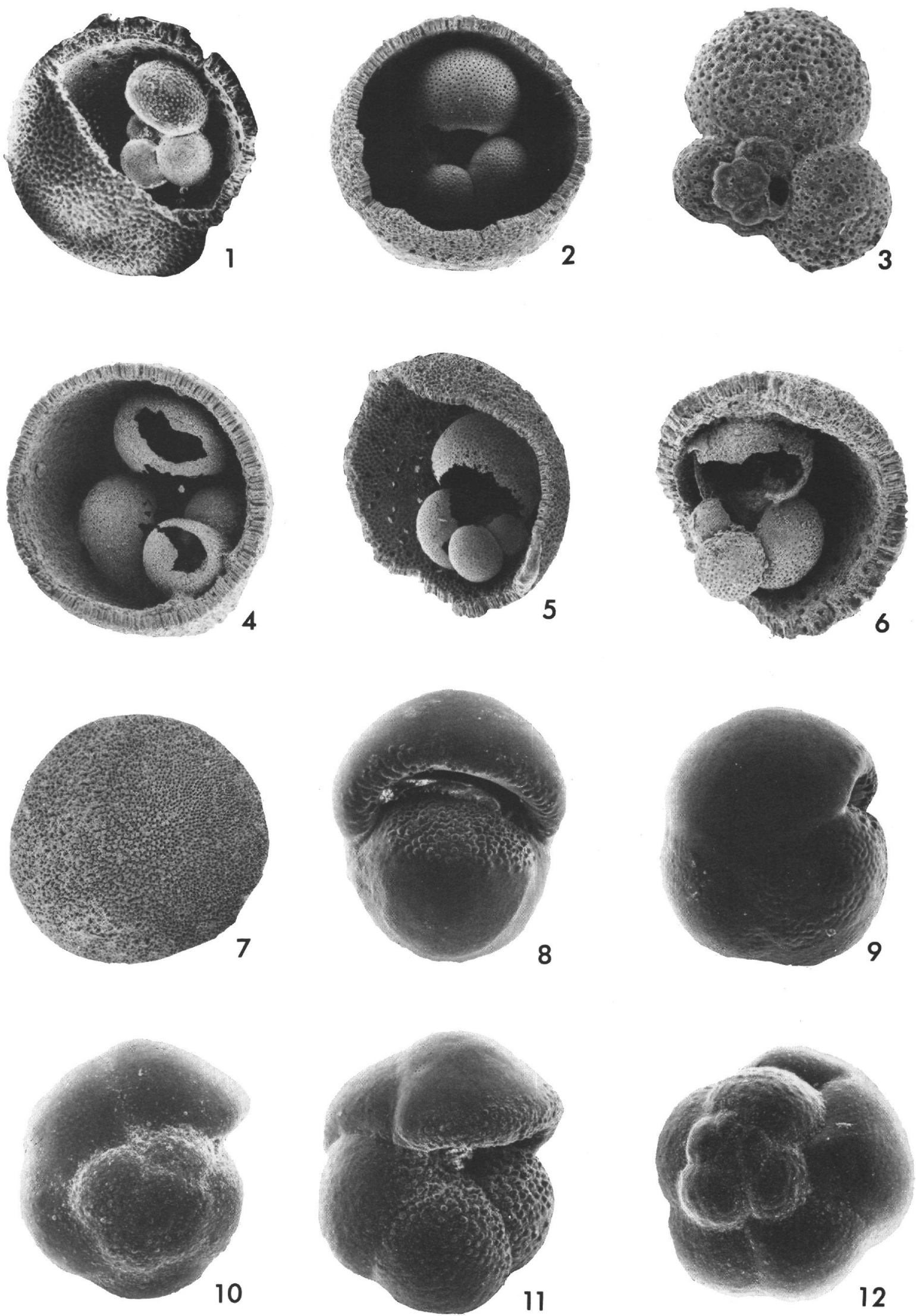


\section{PLATE 21}

Figure $1 \quad$ Pulleniatina primalis Banner and Blow. 21-206-21-3, 30-32 cm; Side view; $\times 94$.

Figures 2-6 Sphaeroidinella dehiscens (Parker and Jones).

2. 21-206-13, CC; Side view; $\times 63$.

3. 21-206-21, CC; Apertural view; $X 64$.

4. 21-206-3-3, 148-150 cm; Side view; $X 44$.

5. 21-206-6, CC; Apertural view; $X 68$.

6. 21-206-14, CC; Side view; $X 62$.

Figure $7 \quad$ Sphaeroidinella seminulina (Schwager) 21-210-19, CC; Umbilical view; X 100;

Figures 8-10 Sphaeroidinella subdehiscens Blow.

8. Umbilical view; $\times 60$.

9. Spiral view; $X 98$.

10. 21-210-19, CC; Spiral view; $\times 104$.

Figure $11 \quad$ Sphaeroidinella sp.

21-206-14, CC; Umbilical view; X104.

Figures 12-15 Sphaeroidinella seminulina (Schwager).

12. Umbilical view; $\times 104$.

13. Umbilical view; $\times 126$.

14. Umbilical view; $\times 70$.

15. 21-206-14, CC; Spiral view; $\times 83$. 
PLATE 21
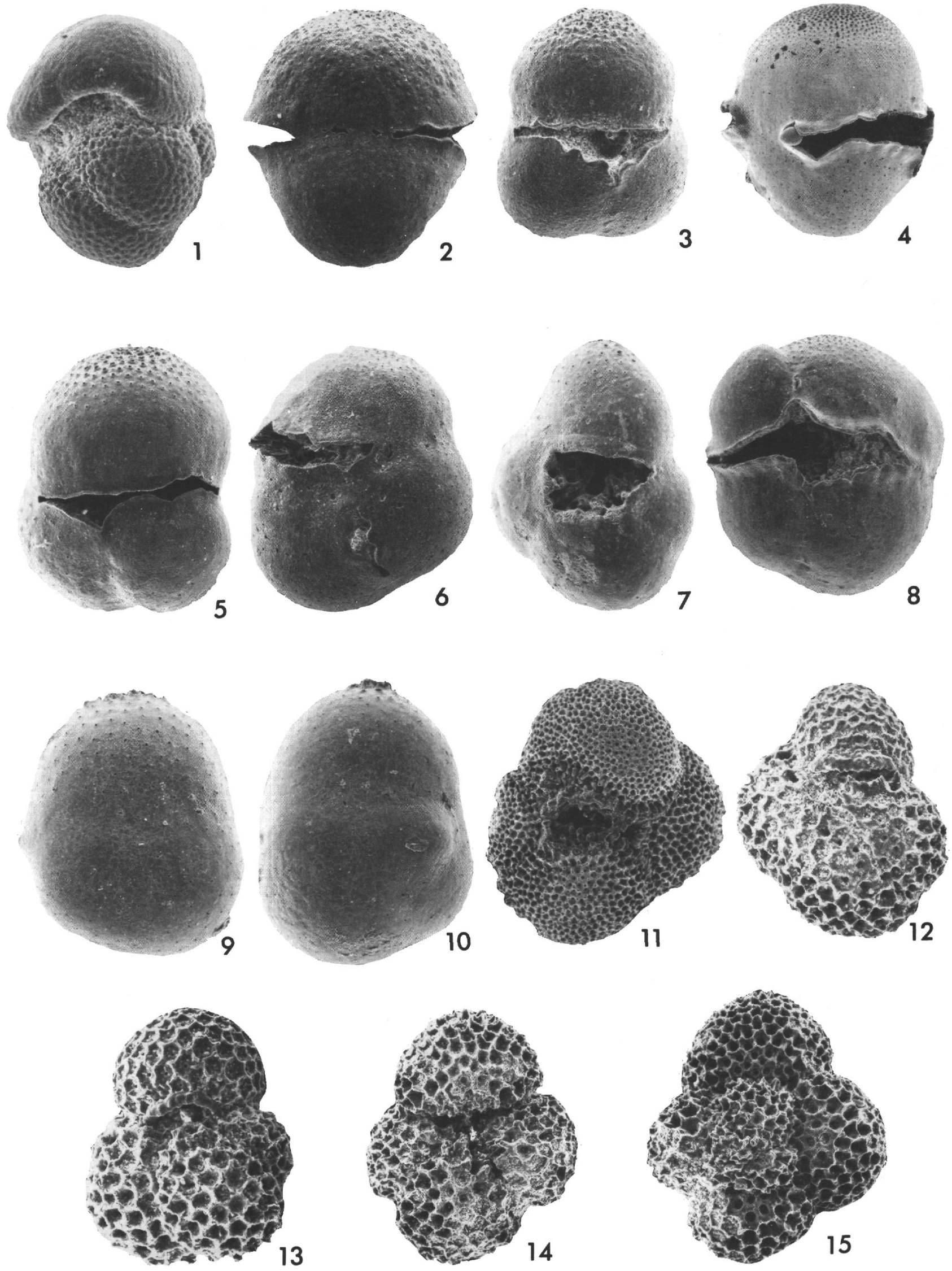